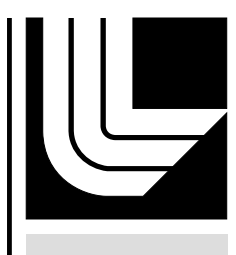

LAW RENCE LIVERMORE N A T IO N A L LABORATORY
Tantalum Disk Impacts on Tantalum Faced LX-04 Targets

K. L. Poormon, K. S. Vandersall

February 7, 2011 
This document was prepared as an account of work sponsored by an agency of the United States government. Neither the United States government nor Lawrence Livermore National Security, LLC, nor any of their employees makes any warranty, expressed or implied, or assumes any legal liability or responsibility for the accuracy, completeness, or usefulness of any information, apparatus, product, or process disclosed, or represents that its use would not infringe privately owned rights. Reference herein to any specific commercial product, process, or service by trade name, trademark, manufacturer, or otherwise does not necessarily constitute or imply its endorsement, recommendation, or favoring by the United States government or Lawrence Livermore National Security, LLC. The views and opinions of authors expressed herein do not necessarily state or reflect those of the United States government or Lawrence Livermore National Security, LLC, and shall not be used for advertising or product endorsement purposes.

This work performed under the auspices of the U.S. Department of Energy by Lawrence Livermore National Laboratory under Contract DE-AC52-07NA27344. 


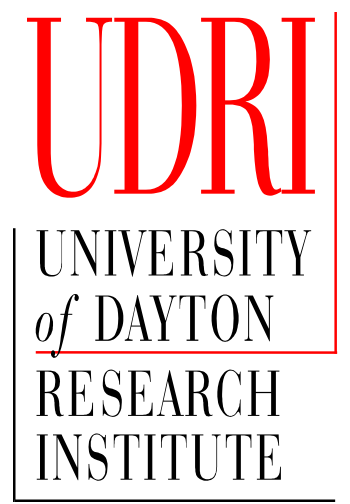

\section{Tantalum Disk Impacts on Tantalum Faced LX-04 Targets}

Prepared by:

KEVIN L. POORMON

November 2010

Prepared for:

Lawrence Livermore National Laboratory 7000 East Avenue

Distribution Statement: Livermore, CA 94550

This report and the information contained within is classified as proprietary. This report should not be duplicated-in whole or in part without obtaining permission from Lawerence TECHNICAL REPORT Livermore National Laboratory UDR-TR-2010-00171 


\title{
Tantalum Disk Impacts on Tantalum Faced LX-04 Targets
}

\author{
November 2010 \\ Final Report \\ Purchase Order Number B56830
}

\author{
Prepared for: \\ Lawrence Livermore National Laboratory \\ 7000 East Avenue \\ Livermore, CA 94550
}

Prepared by:

Kevin L. Poormon

UNIVERSITY OF DAYTON RESEARCH INSTITUTE

Impact Physics Laboratory

300 College Park

Dayton, $\mathrm{OH}$ 45469-0182 


\section{TABLE OF CONTENTS}

$\underline{\text { Section }}$

$\underline{\text { Page }}$

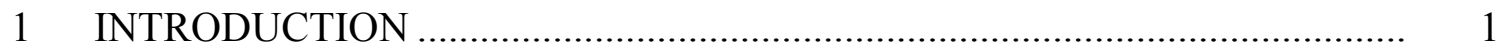

2 TEST DESCRIPTION AND INSTRUMENTATION ….................................. 2

$2.1 \quad$ Test Range Description................................................................. 2

2.2 Test Articles and Test Setup Description........................................... 3

$2.3 \quad$ Projectile Description...................................................................... 6

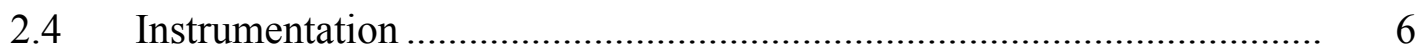

2.4.1 Velocity Measurement ......................................................... 6

2.4.2 Pressure Measurement......................................................... 6

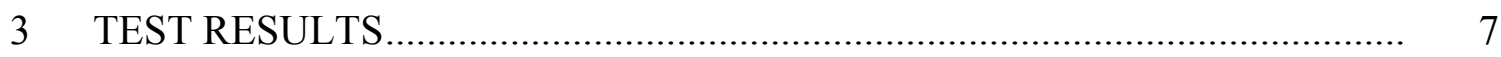

3.1 Impact Test Results.............................................................. 7

3.2 Summary and Conclusions …........................................................ 17

APPENDIX A - Pre-Impact Projectile Radiographs ................................................ 18

APPENDIX B - Pressure Transducer Data .............................................................. 22 


\section{FIGURES}

Figure

1 Photograph of the UDRI Hypervelocity Impact Test Facility ........................... 2

2 Photograph of $30 \mathrm{~mm}$ Powder Gun Setup ...................................................... 3

3 Sketch of the Target Configuration................................................................. 4

4 Photographs of Test Article Setup .............................................................. 5

5 Pre-impact Photo of Target \#1 .................................................................. 8

6 Post Impact View of Target Chamber After Shot 4-2063 .............................. 8

$7 \quad$ Pre-impact Photo of Target \#2 ........................................................................ 9

8 Post Impact View of Target Chamber After Shot 4-2064 ............................... 9

9 Pre-impact Photo of Target \#3 ..................................................................... 10

10 Post Impact View of Target Chamber After Shot 4-2065 .............................. 10

11 Pre-impact Photo of Target \#4 ................................................................... 11

12 Post Impact View of Target Chamber After Shot 4-2066 ................................ 11

13 Pre-impact Photo of Target \#5 ...................................................................... 12

14 Post Impact View of Target Chamber After Shot 4-2067 .............................. 12

15 Pre-impact Photo of Target \#6 .................................................................... 13

16 Post Impact View of Target Chamber After Shot 4-2068 ............................... 13

17 Pre-impact Photo of Target \#7 ...................................................................... 14

18 Post Impact View of Target Chamber After Shot 1-0575 ............................... 14

19 Pre-impact Photo of Target \#8 ....................................................................... 15

20 Post Impact View of Target Chamber After Shot 1-0576 .............................. 15

21 Pre-impact Photo of Target \#9 ...................................................................... 16

22 Post Impact View of Target Chamber After Shot 1-0577 ............................. 16

\section{TABLES}

$\underline{\text { Table }}$

$\underline{\text { Page }}$

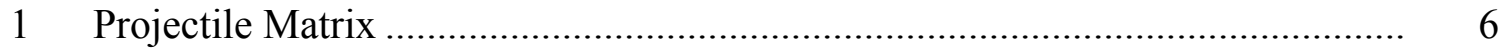

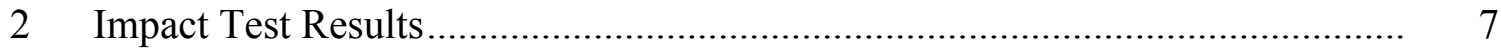




\section{SECTION 1 \\ INTRODUCTION}

This report documents impact tests conducted on tantalum faced LX-04 targets during the period of August 18 - 27, 2010 for Lawrence Livermore National Laboratory (LLNL). The test articles were provided by LLNL. The primary objective was to validate modeling efforts of the experiments.

The impact tests were performed by launching tantalum disks into the targets using a powder gun and a two-stage, light-gas gun. The impact velocities ranged from $590 \mathrm{~m} / \mathrm{s}$ to $3,112 \mathrm{~m} / \mathrm{s}$. Three projectile sizes were launched with diameters of $9.4,14.3$, and $24.7 \mathrm{~mm}$. Data recorded for the tests included projectile weight, impact velocity, and target chamber overpressure. The projectile pitch and yaw were measured with flash radiography. Additionally, LLNL instrumented the targets with Manganin gages to record shock stresses during impact. The testing was conducted in the Impact Physics Laboratory at the University of Dayton Research Institute.

This work was conducted under LLNL Purchase Order Number B568630. Technical direction was provided by Mr. Kevin Vandersall of LLNL. Mr. Vandersall and Mr. Frank Garcia of LLNL witnessed the tests. University of Dayton project supervision was provided by Mr. Daniel R. Bowman, Head, Aerospace Mechanics Division, and Mr. Kevin L. Poormon, Impact Physics Group Leader. Mr. Poormon was also the Principal Investigator with assistance provided by Mr. Mark Collins and Mr. Kevin Fedon. 


\section{SECTION 2 \\ TEST DESCRIPTION AND INSTRUMENTATION}

\subsection{TEST RANGE DESCRIPTION}

This test program was conducted on two gun Ranges in the Impact Physics Laboratory at the University of Dayton Research Institute. Range 4, a 50mm/20mm two-stage, light-gas gun was used for the shots with the 9.4 and $14.3 \mathrm{~mm}$ diameter projectiles. The $24.7 \mathrm{~mm}$ diameter projectiles were launched on Range 8 which is normally configured as a $75 \mathrm{~mm} / 30 \mathrm{~mm}$ two stage, light-gas gun but for this tests series, the range was set up with a $30 \mathrm{~mm}$ powder gun barrel. A photograph of the gun ranges are shown in Figures 1 and 2. The projectiles were installed in a two-piece plastic sabot with a cavity sized to fit the projectile. This launch package was then loaded into the launch tube and fired at the test article. After launch, the sabot was stripped away from the projectile by a steel sabot stripper plate located ahead of the target. The projectile velocity was measured while the projectile was in free-flight with multiple laser/photodetector stations positioned along the projectile flight path. The impact tests were performed in a near vacuum of between $30 \mathrm{~mm}$ and $40 \mathrm{~mm}$ of air pressure.

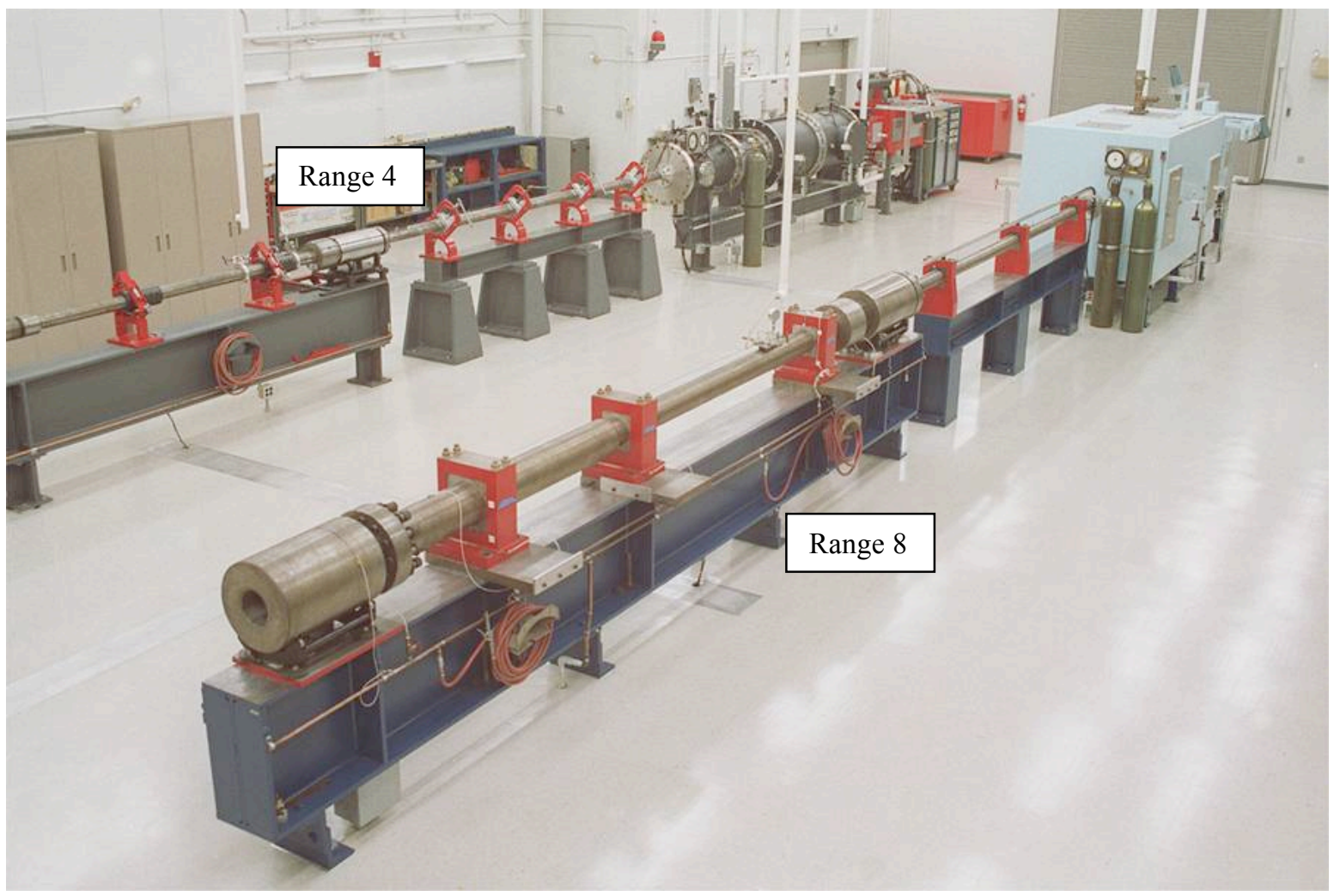

Figure 1. Photograph of the UDRI Hypervelocity Impact Test Facility. 


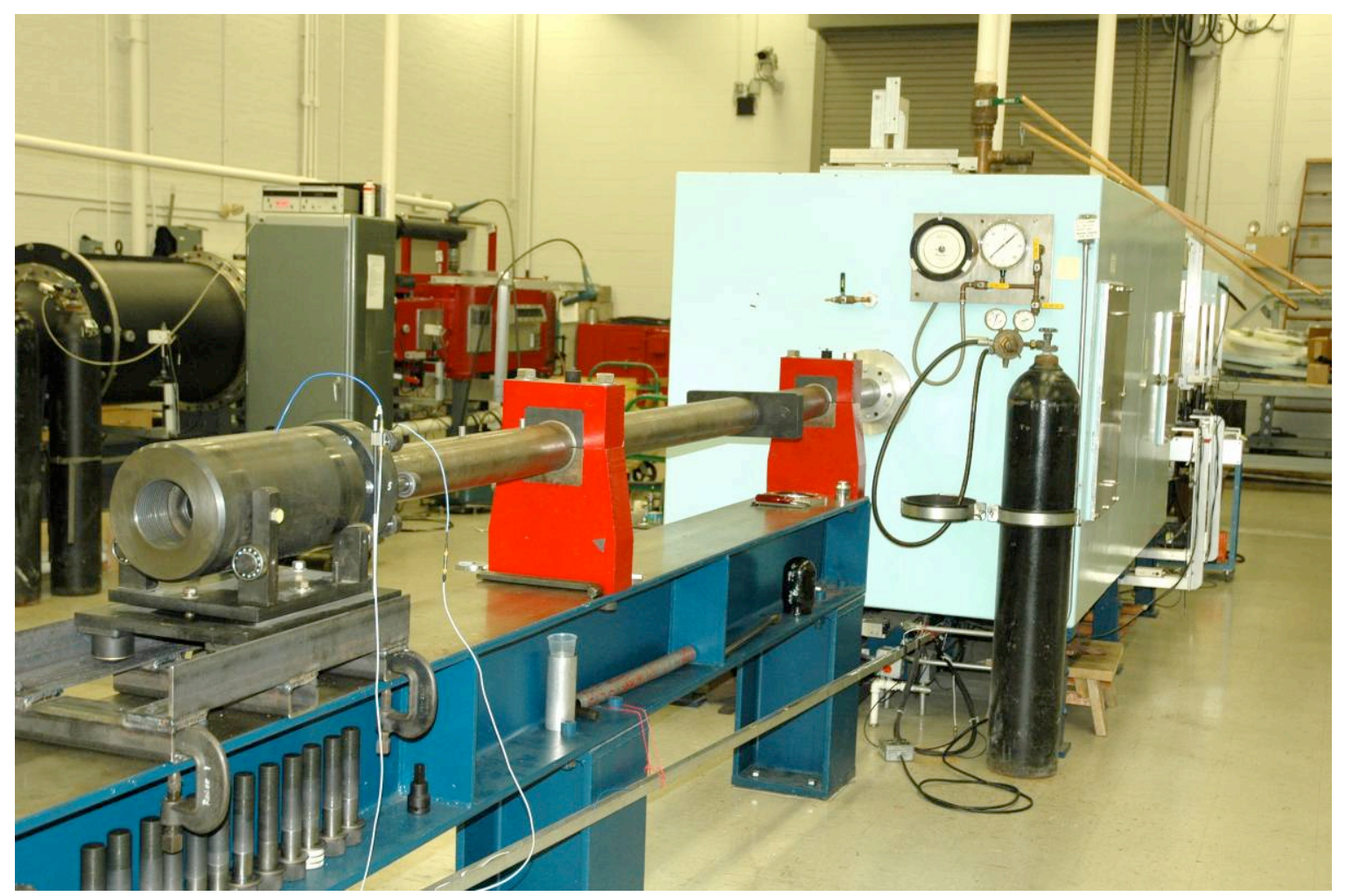

Figure 2. Photograph of 30 mm Powder Gun Setup.

\subsection{TEST ARTICLES AND TEST SETUP DESCRIPTION}

The test articles for this program were $90 \mathrm{~mm}$ diameter LX-04 explosive with the front face covered by $2.8 \mathrm{~mm}$ thick tantalum and the back face covered by $10 \mathrm{~mm}$ thick Teflon. The explosive was either one $10 \mathrm{~mm}$ thick layer or two $5 \mathrm{~mm}$ thick layers and weighed between 118 $\mathrm{g}$ to $119 \mathrm{~g}$. UDRI provided the tantalum front facing to LLNL who assembled the target with imbedded manganin gages. A 6-inch diameter by 0.25 -inch thick aluminum ring was bonded to the back of the Teflon and the aluminum ring was bolted to a phenolic mounting ring as shown in the sketch of Figure 3. A 3/16" thick Lexan plate with a 3" diameter hole was placed on the front of the target and bolted to the aluminum ring to ensure that the tantalum, LX-04 layers, and Teflon did not have gaps between them. The target's phenolic ring was bolted to Lexan standoff rods that positioned the target in the middle of a 36-inch by 36-inch by 42 -inch long target chamber. A string was used to take the weight off the rods and ensure the impact was centered on the face of target The impact angle was $90^{\circ}$. Alignment of the impact location was accomplished with the use of a bore scope that was aligned to the gun barrel center line. Photographs of the target setup are shown in Figure 4. 


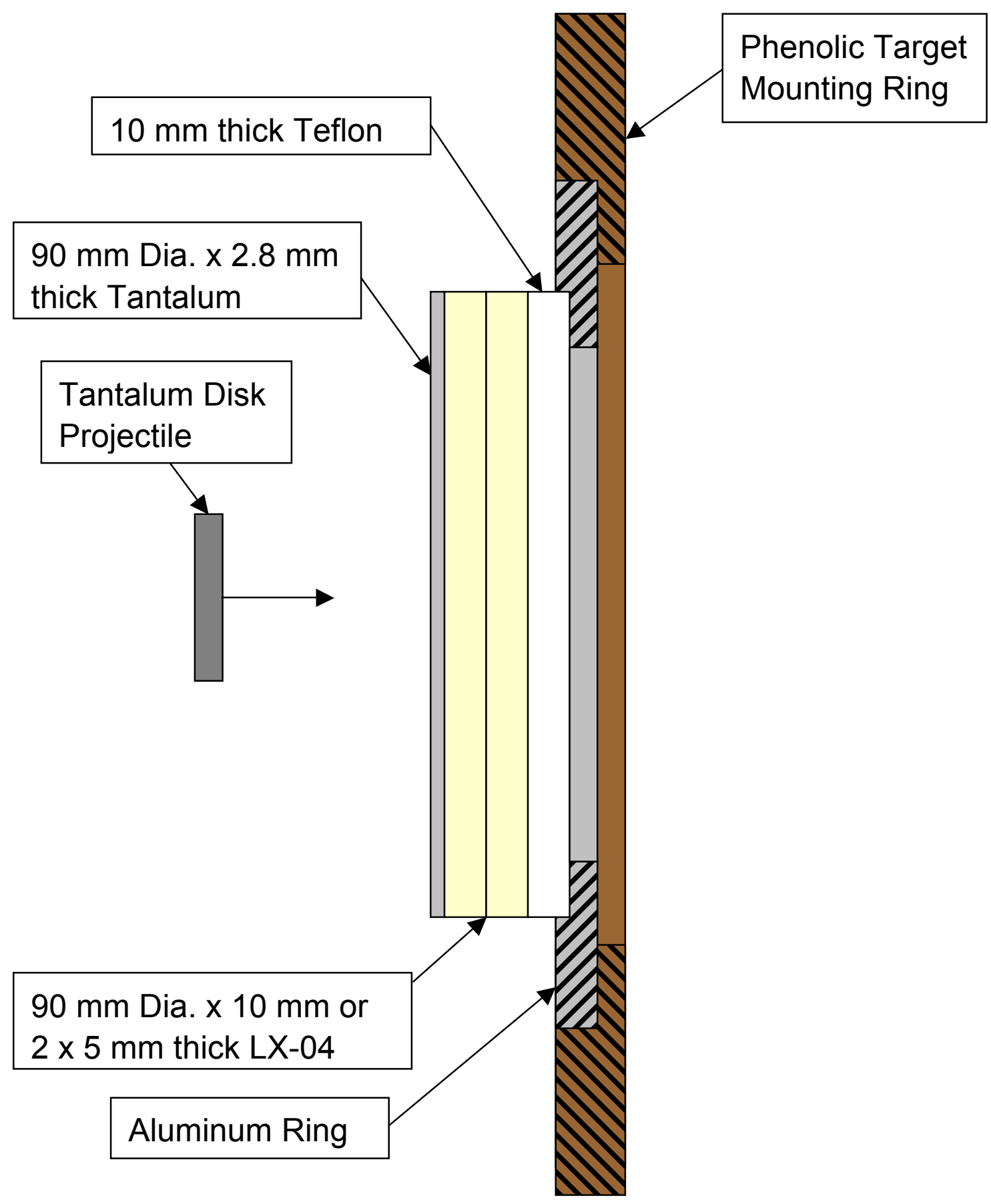

Figure 3. Sketch of the Target Configuration. 

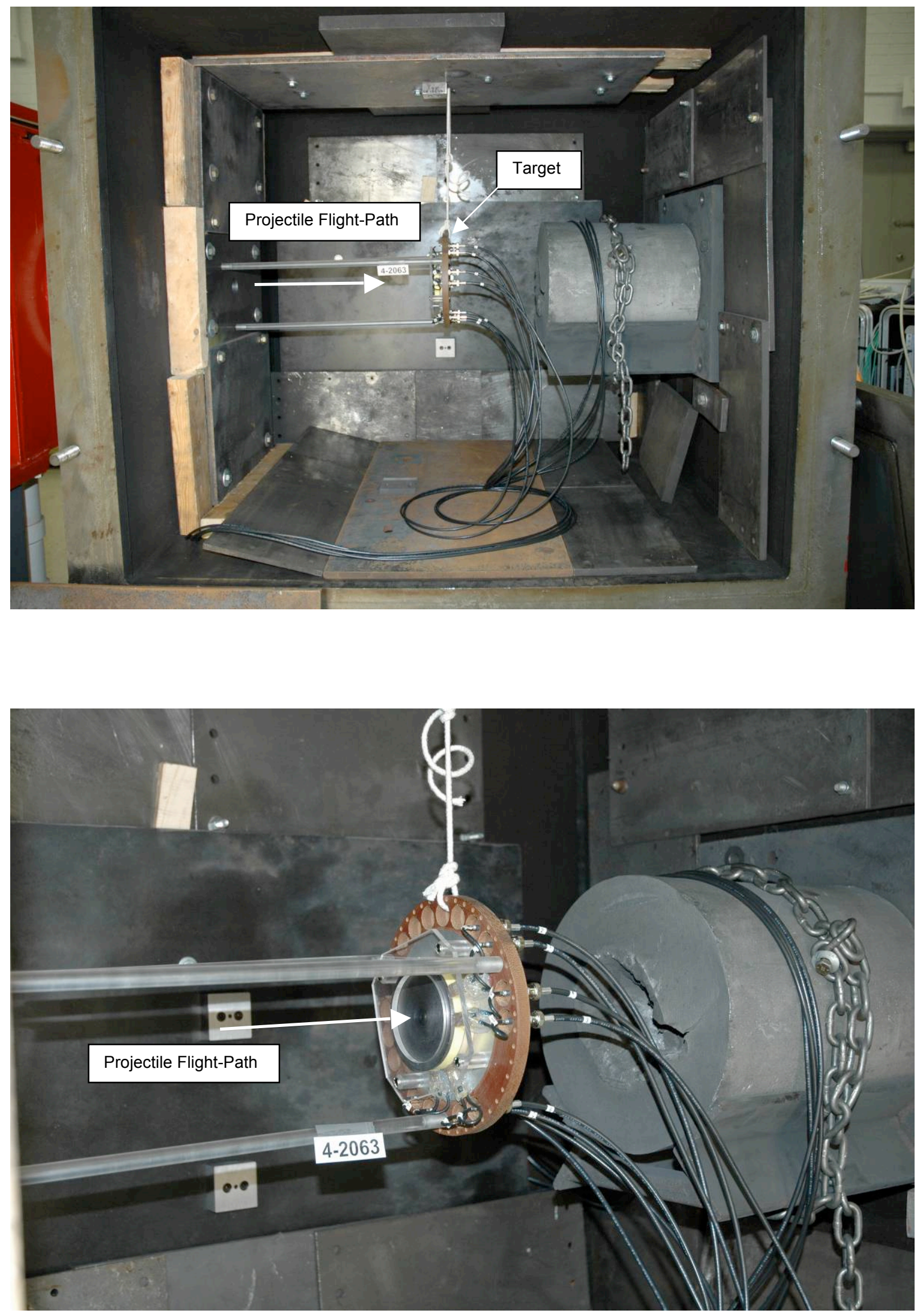

Figure 4. Photographs of Test Article Setup.

\subsection{PROJECTILE DESCRIPTION}


The projectiles for these tests were tantalum discs provided by UDRI. The projectile sizes with the original nominal impact velocities are provided in Table 1 . The actual projectile dimensions were measured with a micrometer and the projectile was weighed using a Mettler $\mathrm{H} 10$ analytic balance with an accuracy of $\pm 0.0002 \mathrm{~g}$.

TABLE 1. PROJECTILE MATRIX

\begin{tabular}{|c|c|c|c|c|}
\hline Projectile & Mass, $g$ & Length, $\mathrm{mm}$ & Diameter, $\mathrm{mm}$ & Velocity, $\mathrm{km} / \mathrm{sec}$ \\
\hline 1 & 16 & 2 & 24.7 & $0.8,1.0,1.2$ \\
\hline 2 & 8 & 3 & 14.3 & $1.5,1.85,2.2$ \\
\hline 3 & 4 & 3.5 & 9.4 & $2.5,3.0,3.7$ \\
\hline
\end{tabular}

\subsection{INSTRUMENTATION}

The data collected from the impact tests included projectile weight and projectile impact velocity. Orthogonal pre-impact images of the projectile were captured 47 inches ahead of the target using $180 \mathrm{kv}$ Field Emissions flash radiography Documentary photographs of each test article were also taken after testing. All recording instruments are calibrated annually.

\subsubsection{Velocity Measurement}

The projectile velocity was measured with four HeNe laser/photodetector stations positioned between the gun muzzle and the target. Each laser projected a beam that intersected the projectile trajectory normal to the trajectory and illuminated an opposing photodetector station. When the projectile interrupted the beam, the interruption time was recorded by an HBM Genesis data acquisition system operating with a sampling rate of $10 \mathrm{Mhz}$. The impact velocity was calculated by dividing the distance traveled between the laser/photodetector stations by the difference in the time of arrivals recorded between the laser/photodetector stations. Velocity measurement accuracy is better than $0.5 \%$.

\subsubsection{Pressure Measurement}

The overpressure in the target chamber was measured by three model 111A26 PCB Piezotronics pressure transducers. The pressure transducers were mounted on steel plates affixed to the target chamber walls in the plane of the LX-04 explosive. One transducer was directly above the target 16 inches away from the target centerline. The second transducer was mounted to the side of the target 16 inches away from the target centerline. The third transducer was mounted 7.5 inches below the side transducer. 


\section{SECTION 3}

TEST RESULTS

\subsection{IMPACT TEST RESULTS}

A total of 9 tests were conducted in this program. Table 2 gives a summary of the test conditions and the test results. The pre-impact radiographs of the projectiles are included in Appendix A. Projectile pitch and yaw was not captured during some tests due to equipment malfunction. Post test photographs of the test articles are shown in Figures 5 through 22. The target chamber pressure data is provided in Appendix B.

TABLE 2. IMPACT TEST RESULTS

\begin{tabular}{|c|c|c|c|c|c|c|c|c|l|}
\hline $\begin{array}{c}\text { Shot } \\
\text { No. }\end{array}$ & $\begin{array}{c}\text { Test } \\
\text { Date }\end{array}$ & $\begin{array}{c}\text { Target } \\
\text { Description }\end{array}$ & $\begin{array}{c}\text { Projectile } \\
\text { Diameter } \\
\mathrm{mm}\end{array}$ & $\begin{array}{c}\text { Projectile } \\
\text { Length } \\
\mathrm{mm}\end{array}$ & $\begin{array}{c}\text { Projectile } \\
\text { Mass } \\
g\end{array}$ & $\begin{array}{c}\text { Projectile } \\
\text { Pitch } \\
\text { Deg }\end{array}$ & $\begin{array}{c}\text { Projectile } \\
\text { Yaw } \\
\text { Deg }\end{array}$ & $\begin{array}{c}\text { Impact } \\
\text { Velocity } \\
\text { Km/sec }\end{array}$ & \multicolumn{1}{|c|}{ Results } \\
\hline \hline $4-2063$ & $8 / 18 / 10$ & $\begin{array}{c}\text { LX-04 } \\
\text { Target \#1 }\end{array}$ & 14.30 & 2.97 & 7.9278 & Unknown & Unknown & 1.877 & Deflagration \\
\hline $4-2064$ & $8 / 19 / 10$ & $\begin{array}{c}\text { LX-04 } \\
\text { Target \#2 }\end{array}$ & 9.45 & 3.51 & 4.0518 & $8.5^{\circ} \mathrm{D}$ & $13.5^{\circ} \mathrm{L}$ & 3.112 & Full Detonation \\
\hline $4-2065$ & $8 / 19 / 10$ & $\begin{array}{c}\text { LX-04 } \\
\text { Target \#3 }\end{array}$ & 9.40 & 3.53 & 4.0361 & Unknown & Unknown & 2.617 & Full Detonation \\
\hline $4-2066$ & $8 / 20 / 10$ & $\begin{array}{c}\text { LX-04 } \\
\text { Target \#4 }\end{array}$ & 9.40 & 3.53 & 4.0412 & $3.0^{\circ} \mathrm{U}$ & $6.0^{\circ} \mathrm{R}$ & 1.788 & Full Detonation \\
\hline $4-2067$ & $8 / 20 / 10$ & $\begin{array}{c}\text { LX-04 } \\
\text { Target \#5 }\end{array}$ & 14.31 & 3.00 & 7.9887 & Unknown & Unknown & 2.084 & Full Detonation \\
\hline $4-2068$ & $8 / 23 / 10$ & $\begin{array}{c}\text { LX-04 } \\
\text { Target \#6 }\end{array}$ & 14.32 & 2.97 & 7.8537 & $1.0^{\circ} \mathrm{U}$ & $0^{\circ}$ & 1.639 & Partial Detonation \\
\hline $1-0575$ & $8 / 26 / 10$ & $\begin{array}{c}\text { LX-04 } \\
\text { Target \#7 }\end{array}$ & 24.66 & 1.99 & 15.8446 & $1.0^{\circ} \mathrm{D}$ & $0.5^{\circ} \mathrm{L}$ & 1.065 & Full Detonation \\
\hline $1-0576$ & $8 / 26 / 10$ & $\begin{array}{c}\text { LX-04 } \\
\text { Target \#8 }\end{array}$ & 24.64 & 1.98 & 15.8303 & $0.5^{\circ} \mathrm{D}$ & $5.5^{\circ} \mathrm{R}$ & 0.922 & Full Detonation \\
\hline $1-0577$ & $8 / 27 / 10$ & $\begin{array}{c}\text { LX-04 } \\
\text { Target \#9 }\end{array}$ & 24.64 & 1.99 & 15.8367 & $3.0^{\circ} \mathrm{U}$ & $1.0^{\circ} \mathrm{R}$ & 0.590 & Deflagration \\
\hline
\end{tabular}




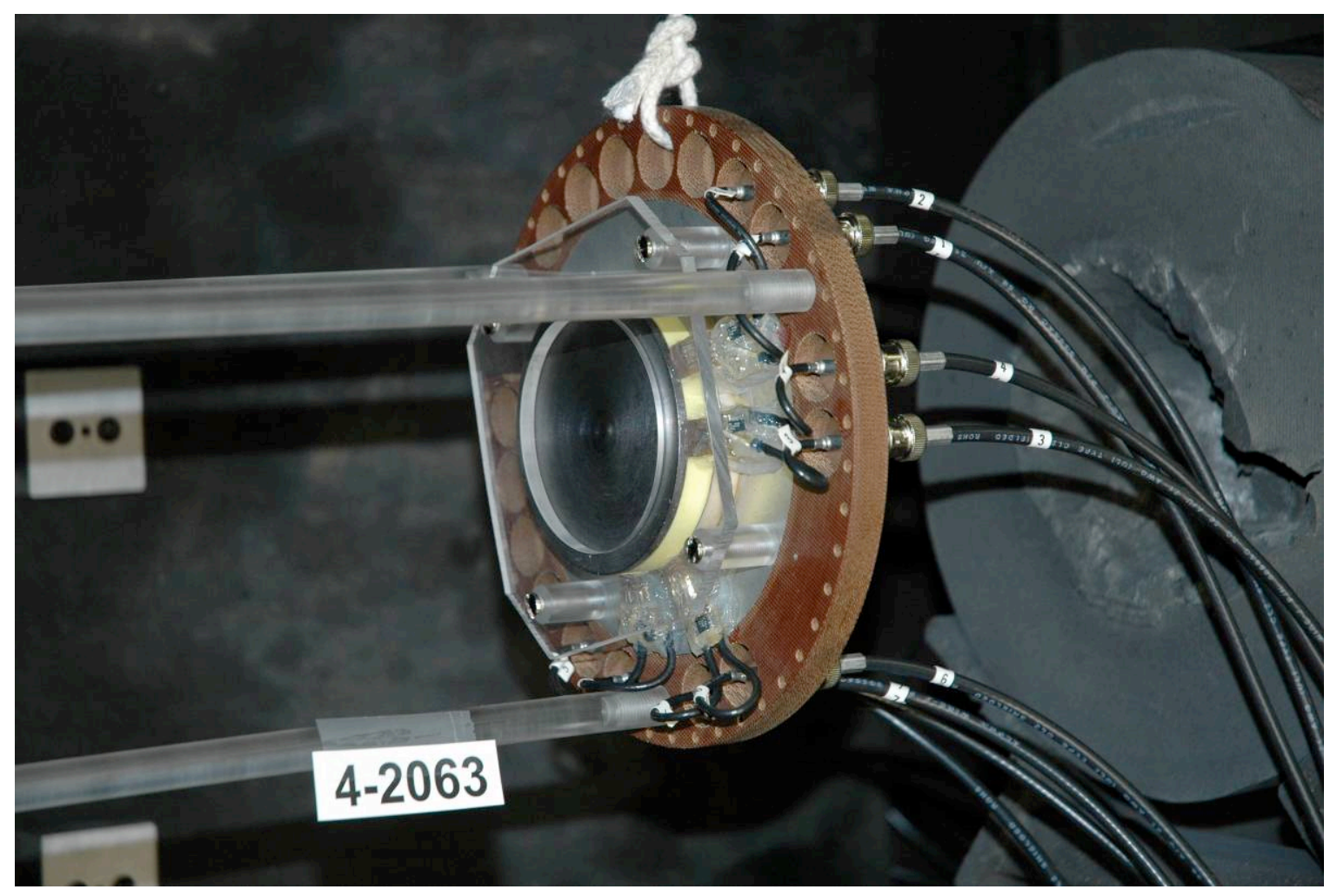

Figure 5. Pre-impact Photo of Target \#1.

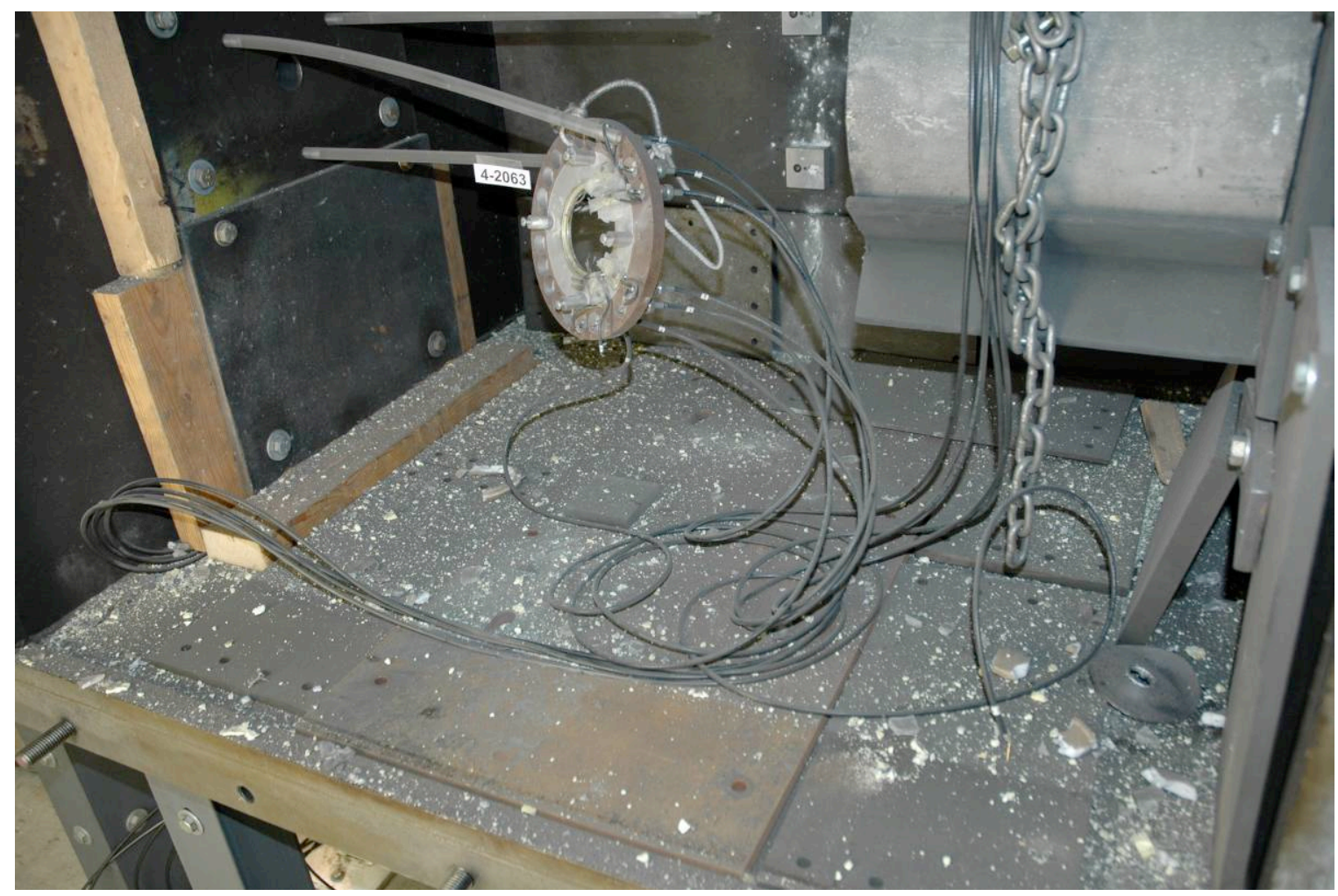

Figure 6. Post Impact View of Target Chamber After Shot 4-2063. 


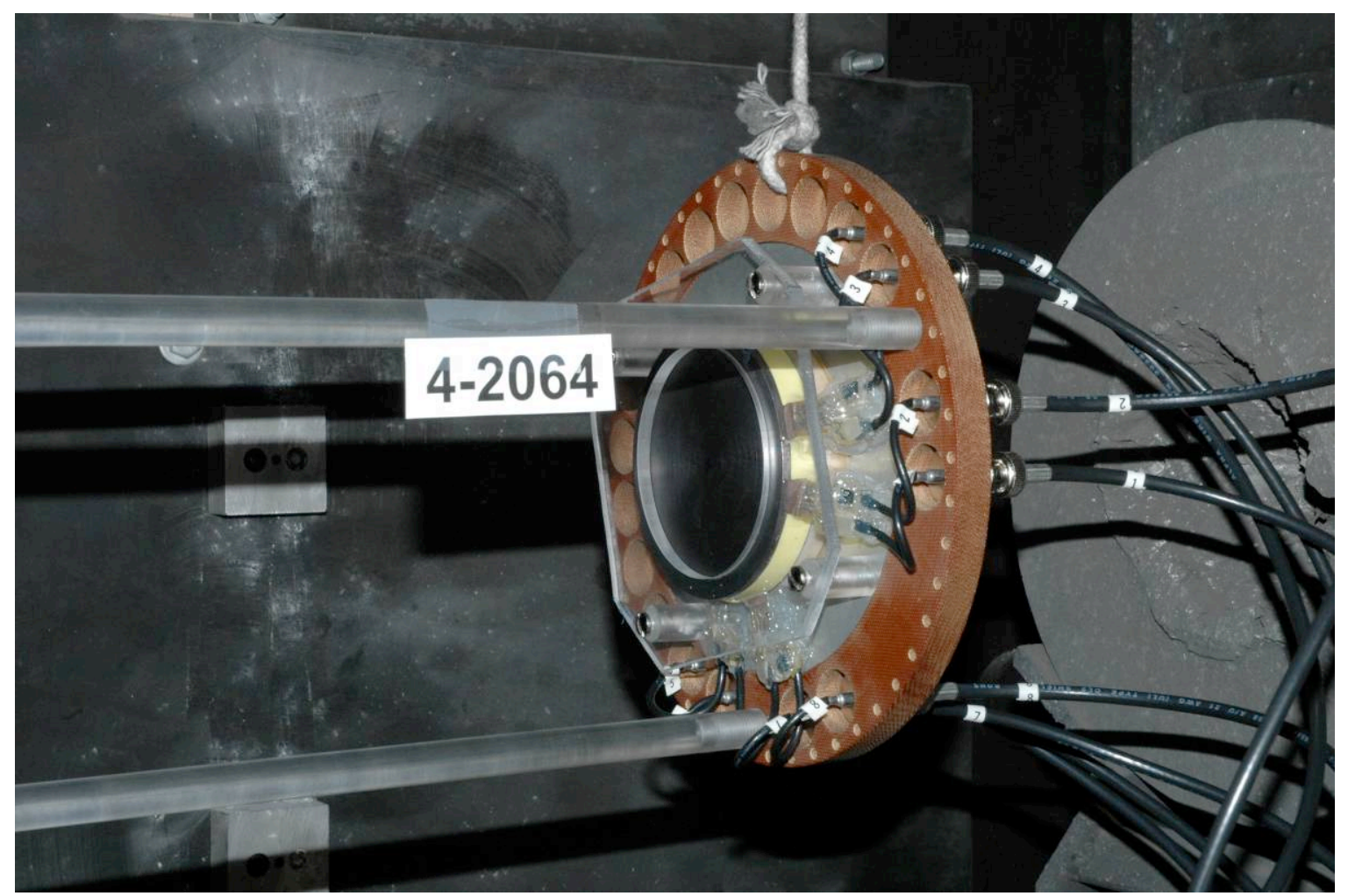

Figure 7. Pre-impact Photo of Target \#2.

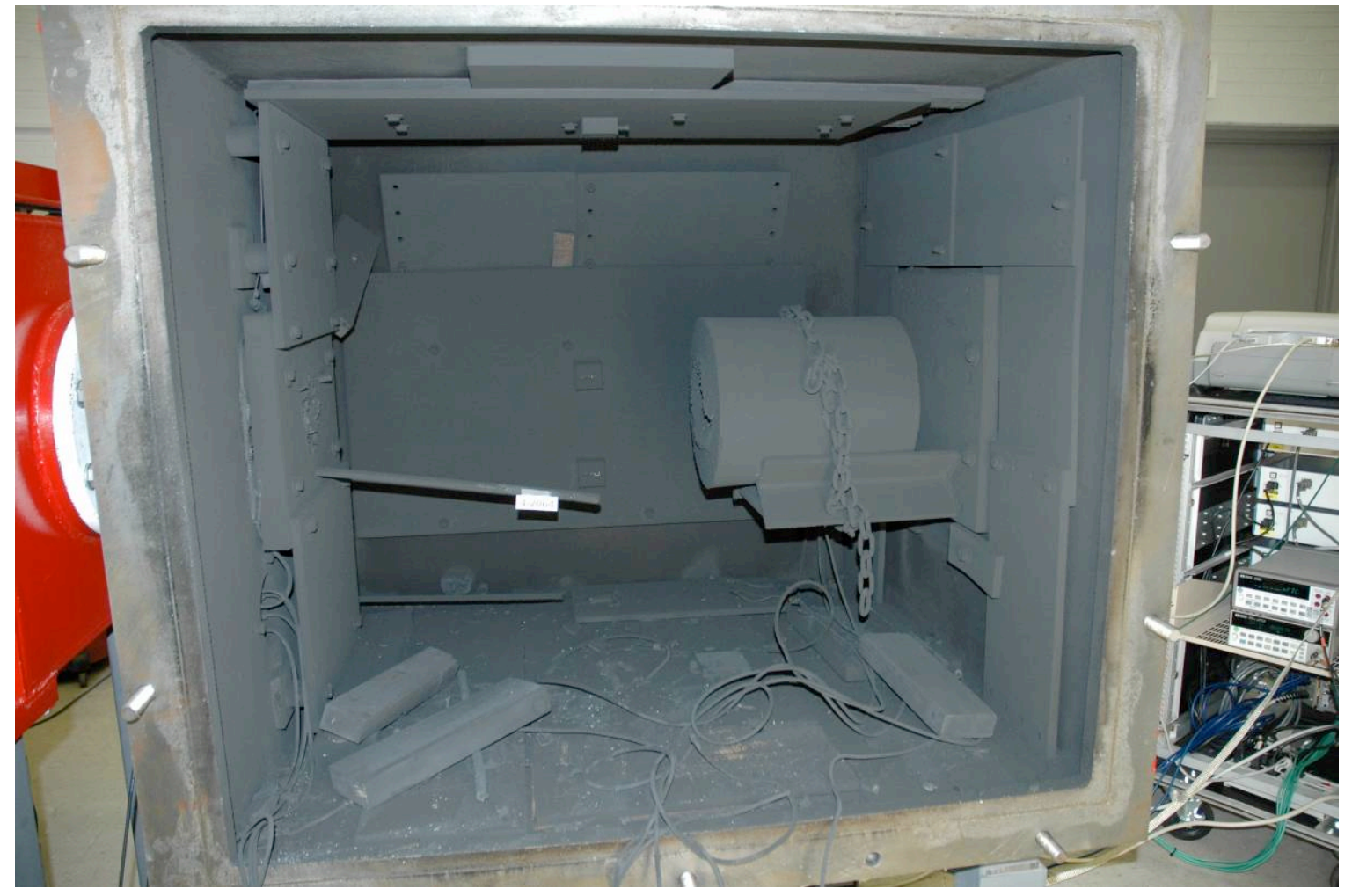

Figure 8. Post Impact View of Target Chamber After Shot 4-2064. 


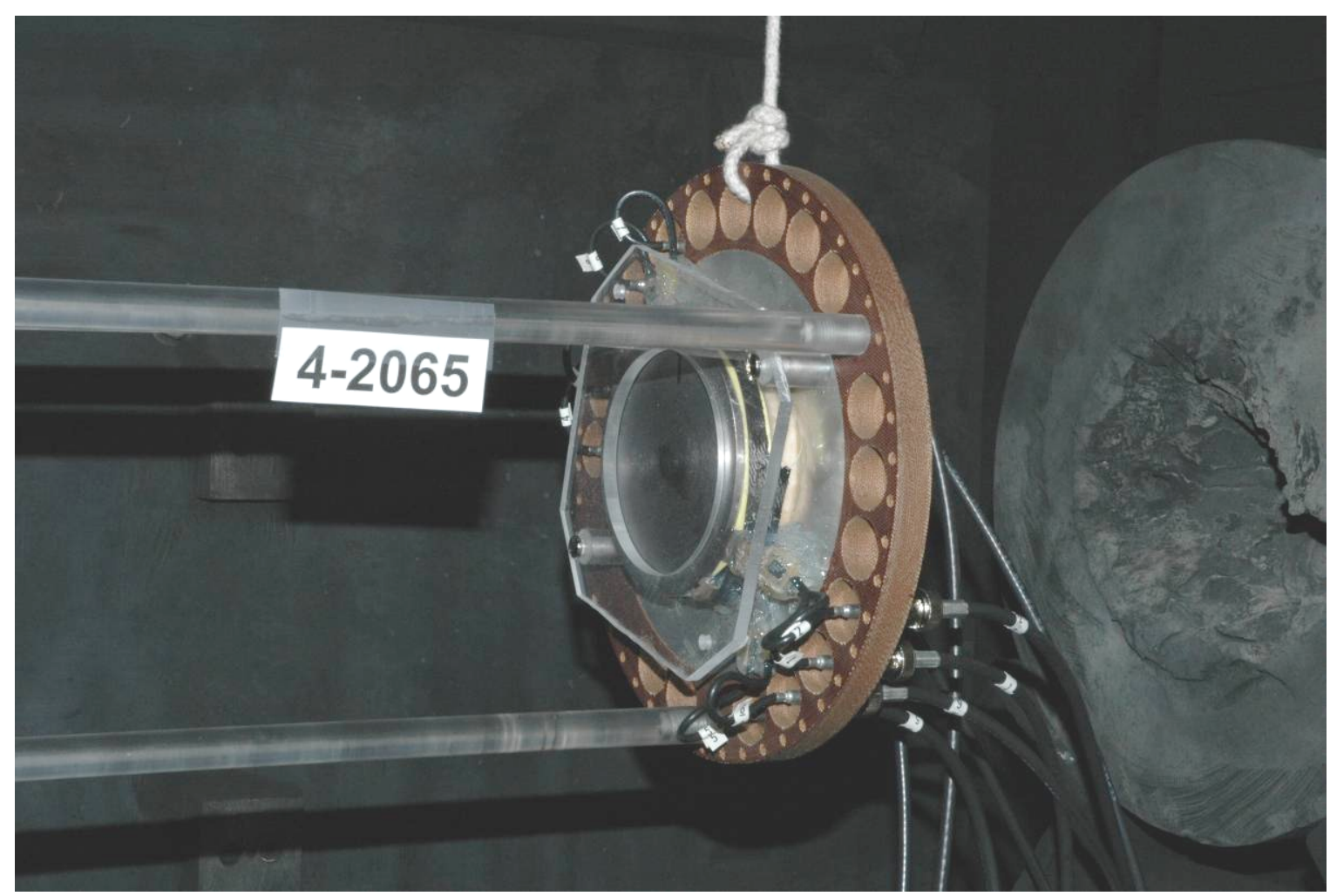

Figure 9. Pre-impact Photo of Target \#3.

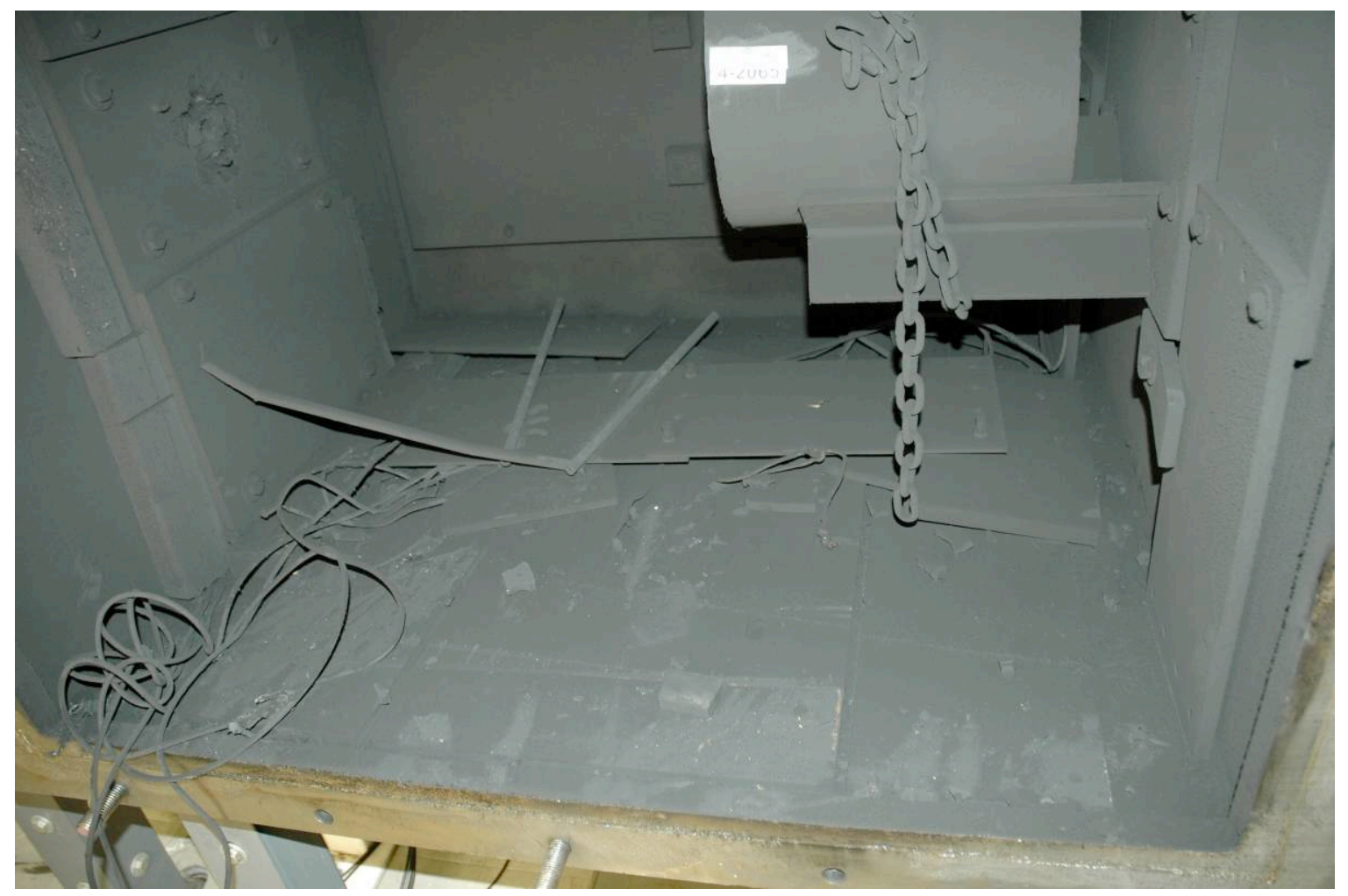

Figure 10. Post Impact View of Target Chamber After Shot 4-2065. 


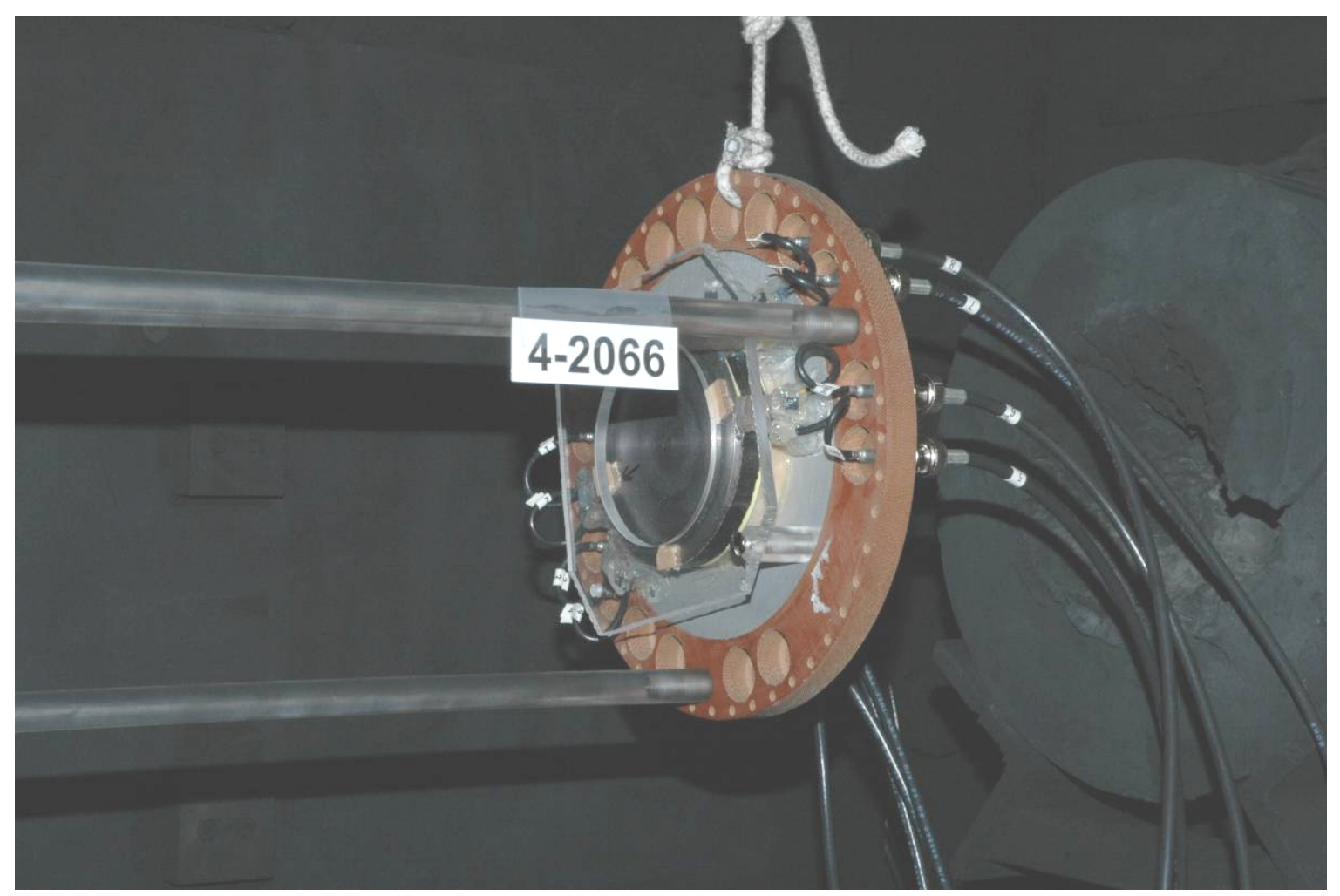

Figure 11. Pre-impact Photo of Target \#4.

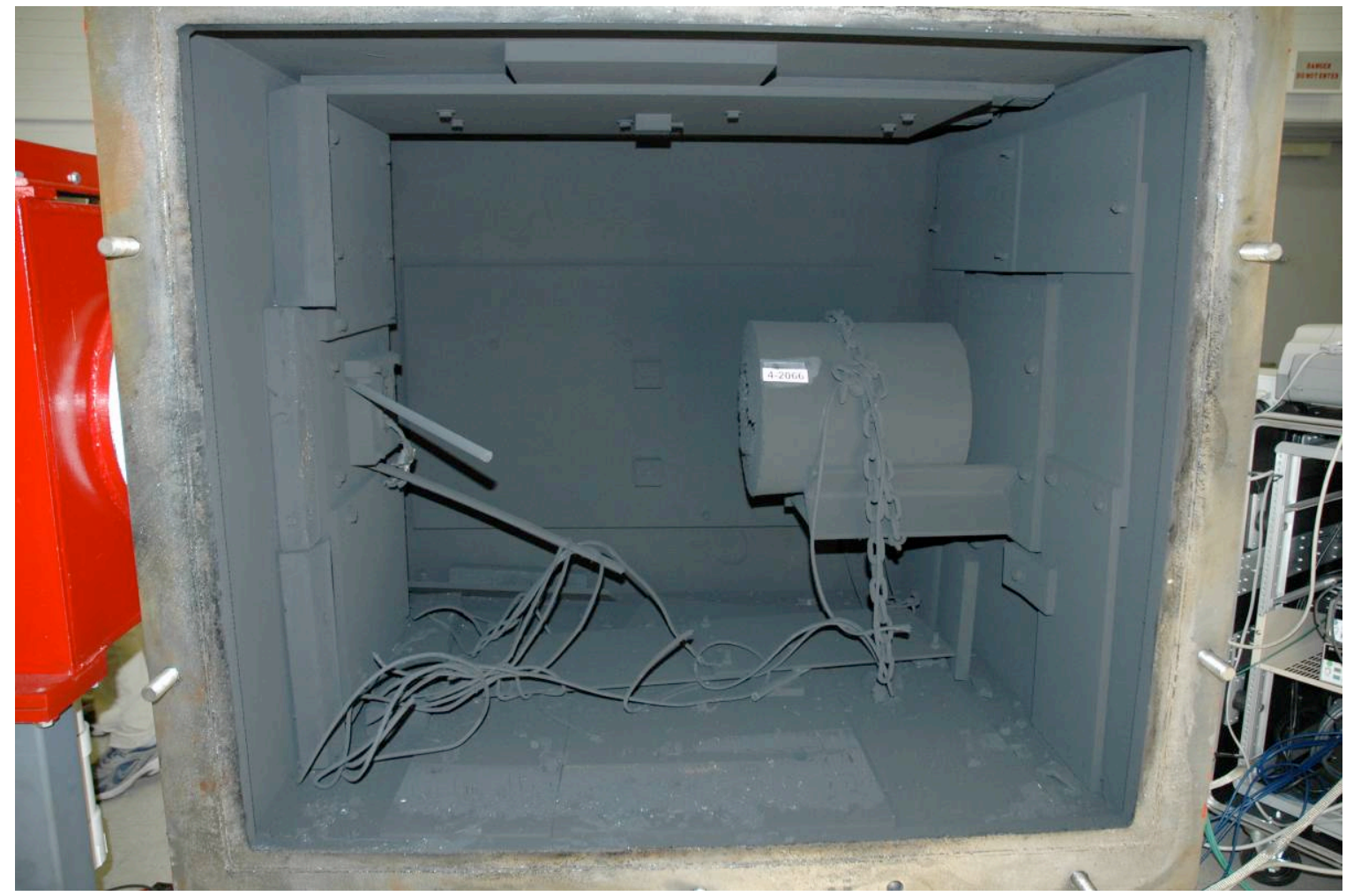

Figure 12. Post Impact View of Target Chamber After Shot 4-2066. 


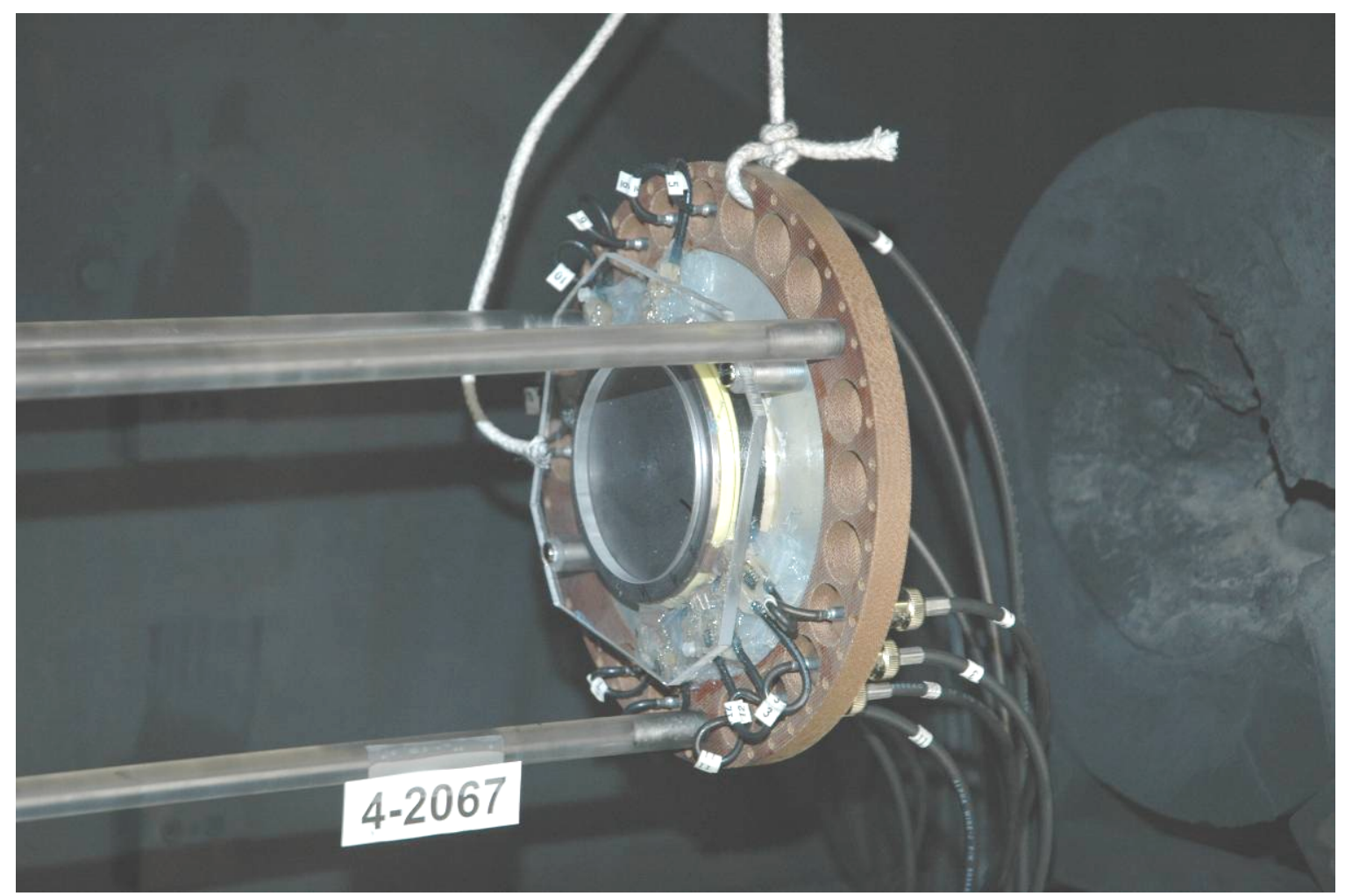

Figure 13. Pre-impact Photo of Target \#5.

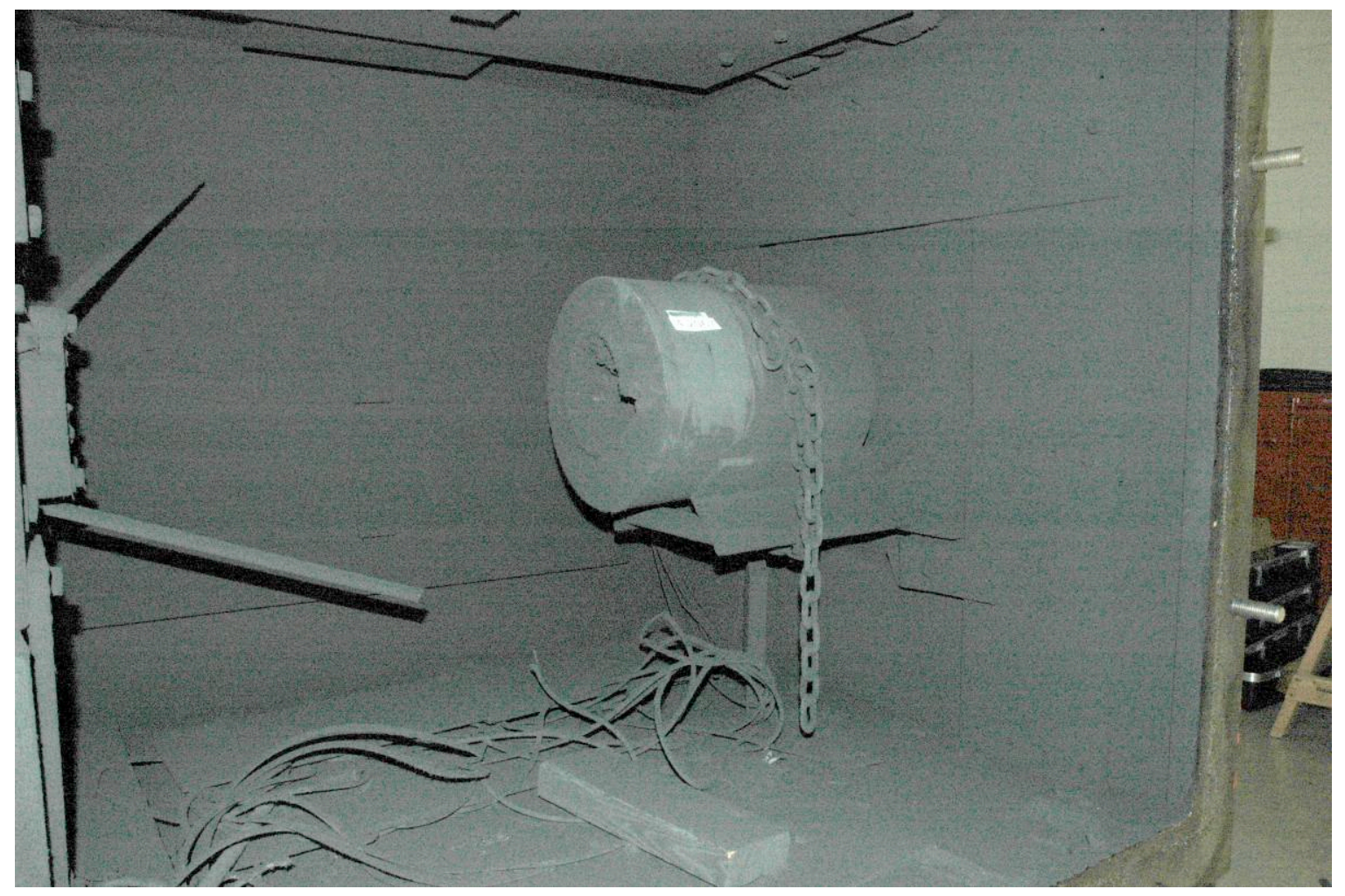

Figure 14. Post Impact View of Target Chamber After Shot 4-2067. 


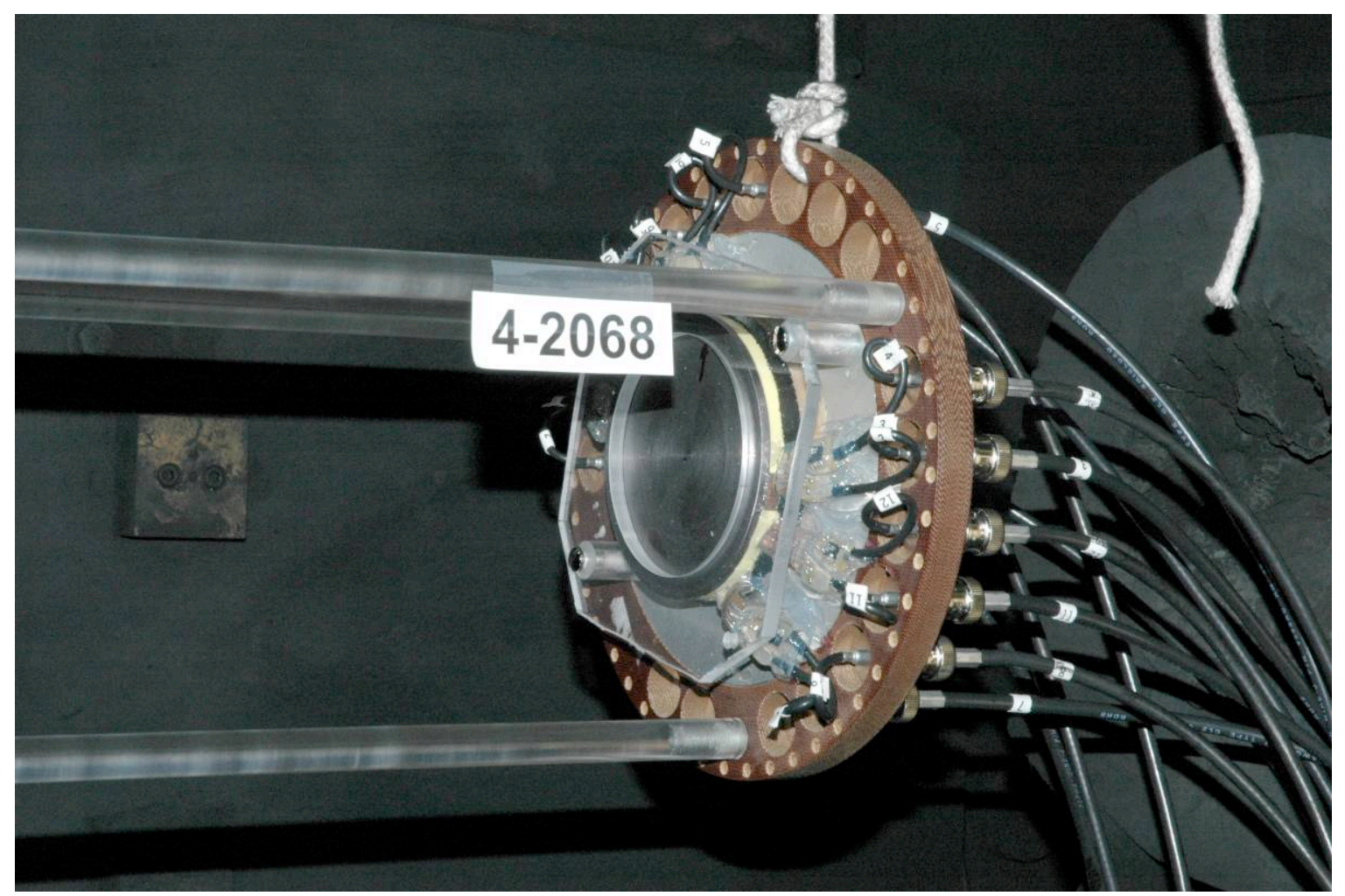

Figure 15. Pre-impact Photo of Target \#6.

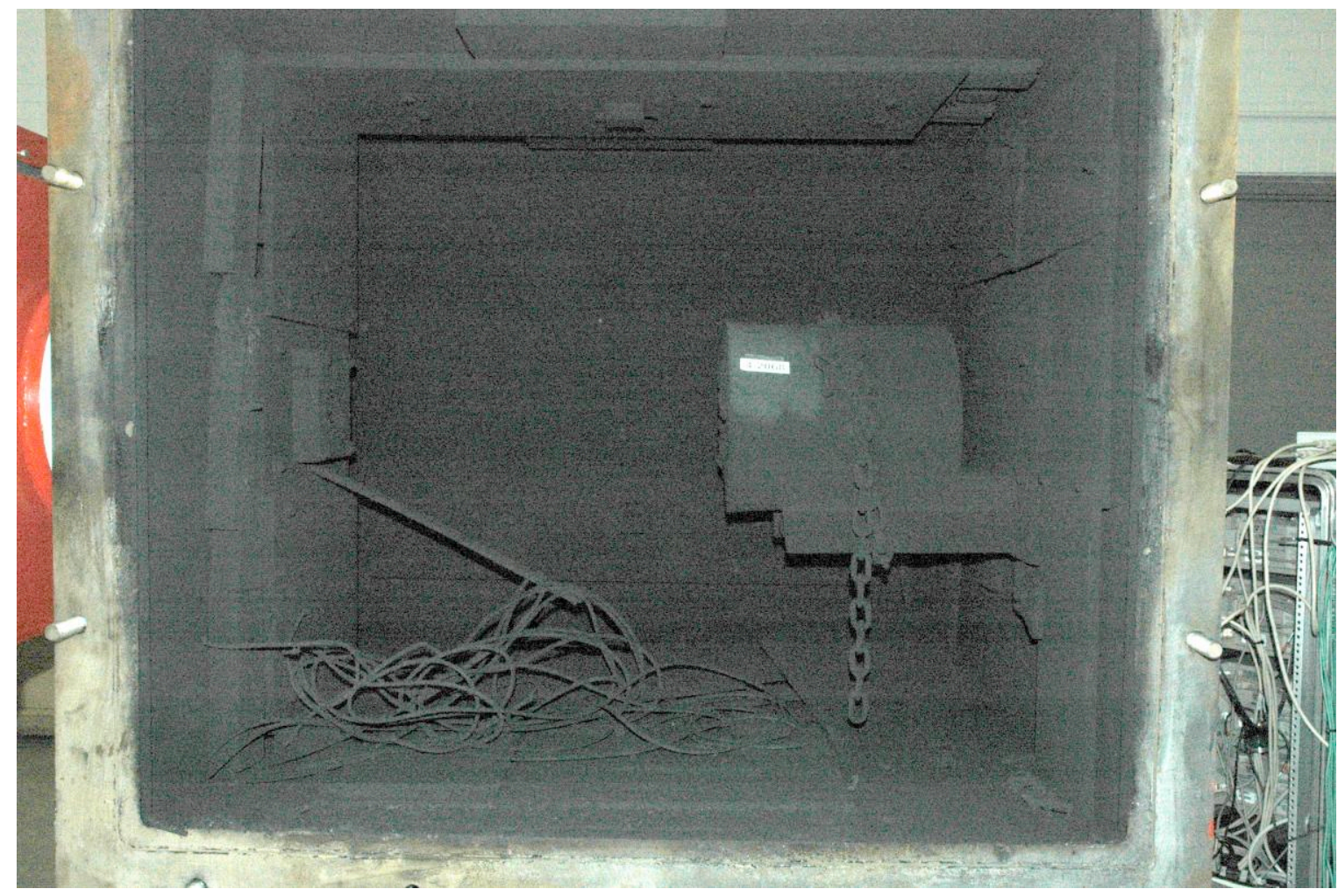

Figure 16. Post Impact View of Target Chamber After Shot 4-2068. 


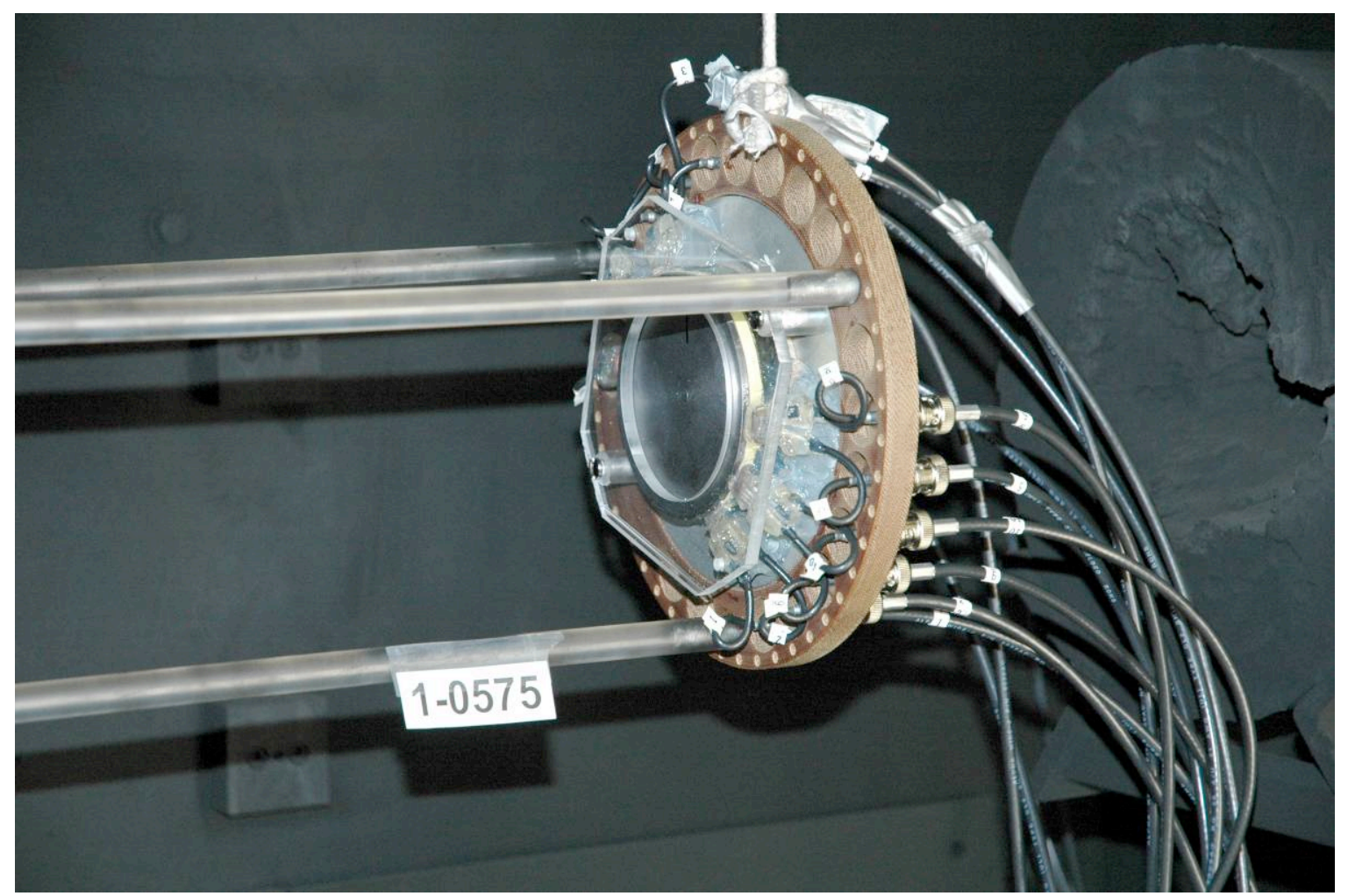

Figure 17. Pre-impact Photo of Target \#7.

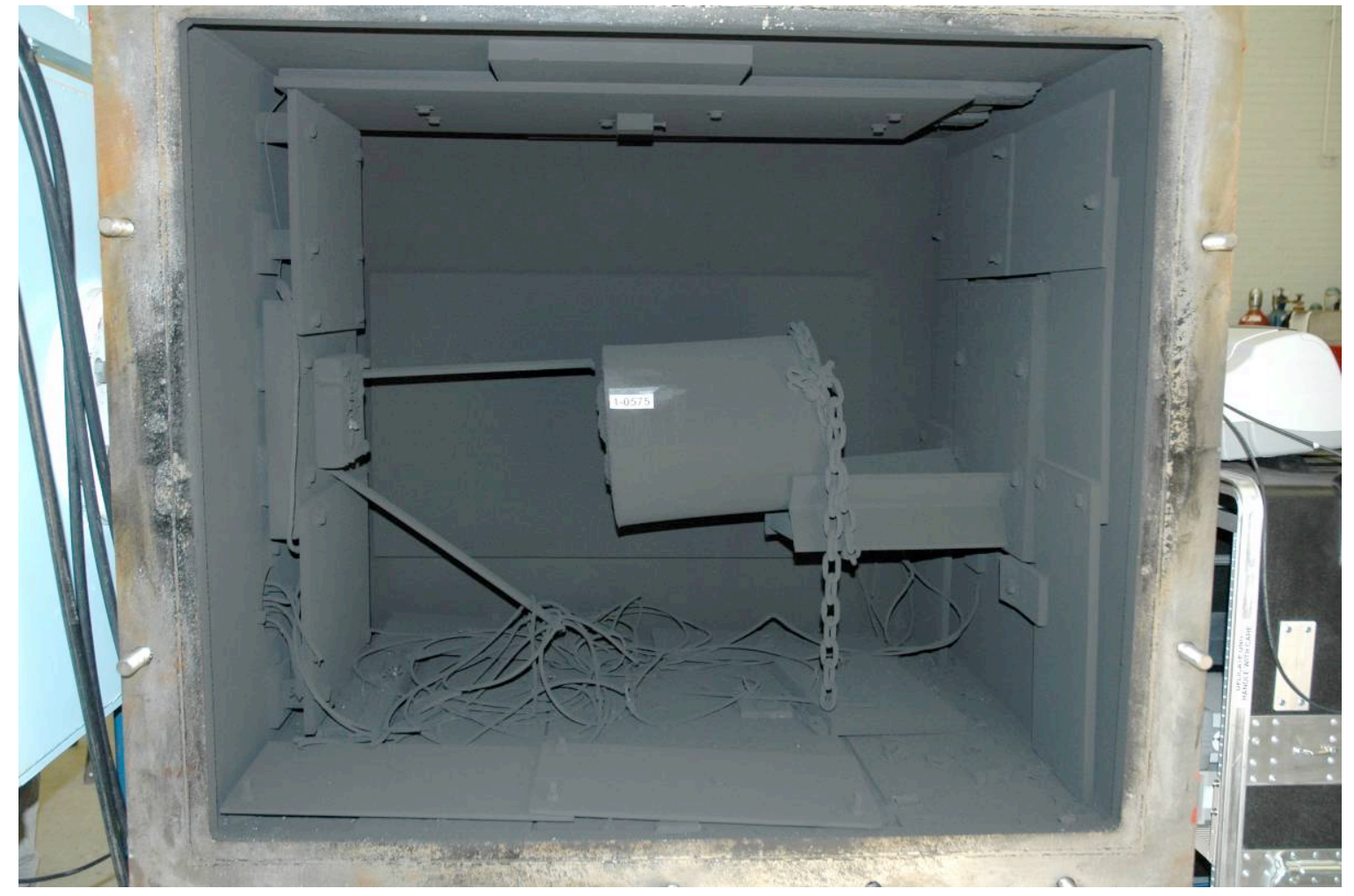

Figure 18. Post Impact View of Target Chamber After Shot 1-0575. 


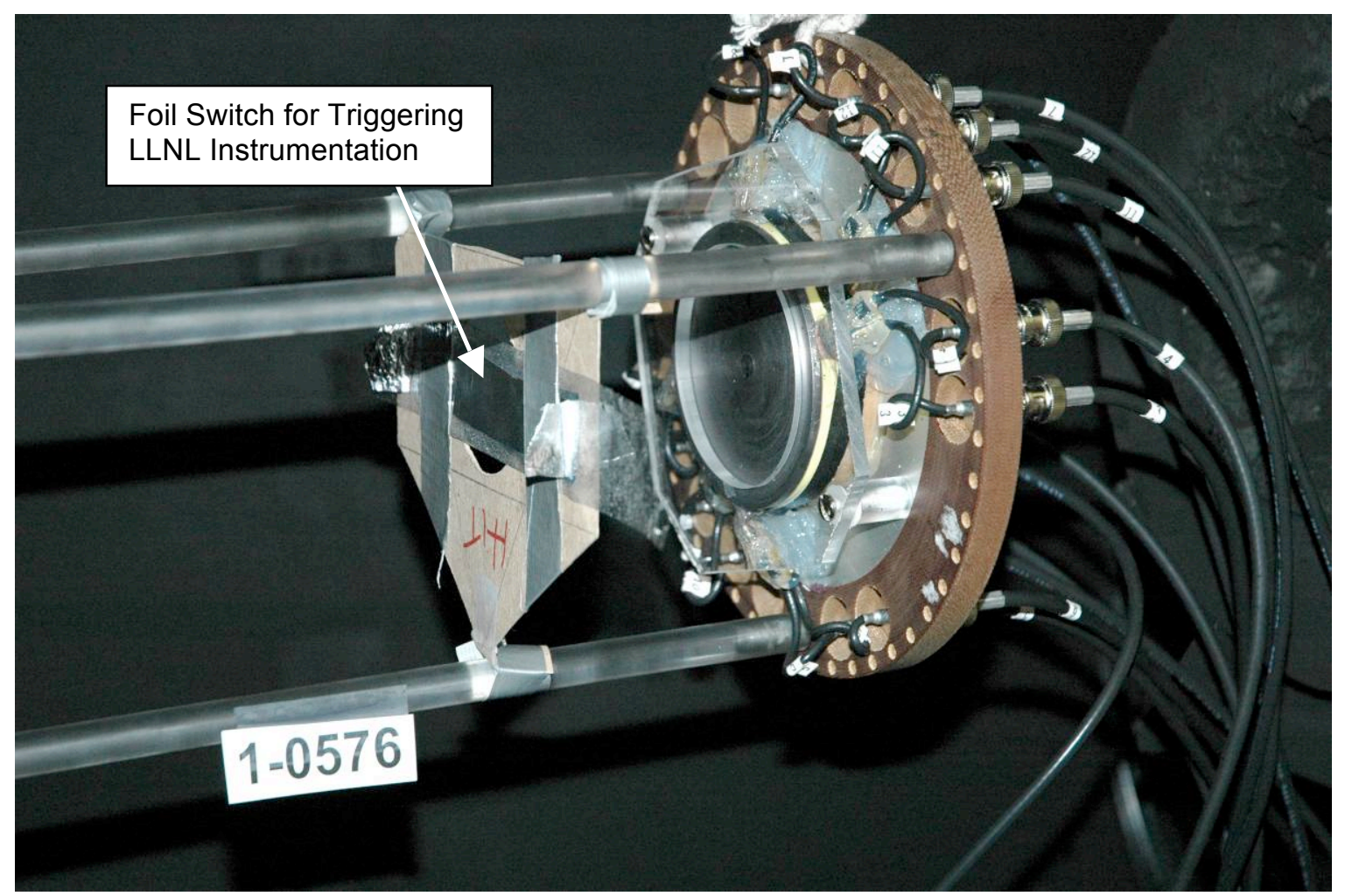

Figure 19. Pre-impact Photo of Target \#8.

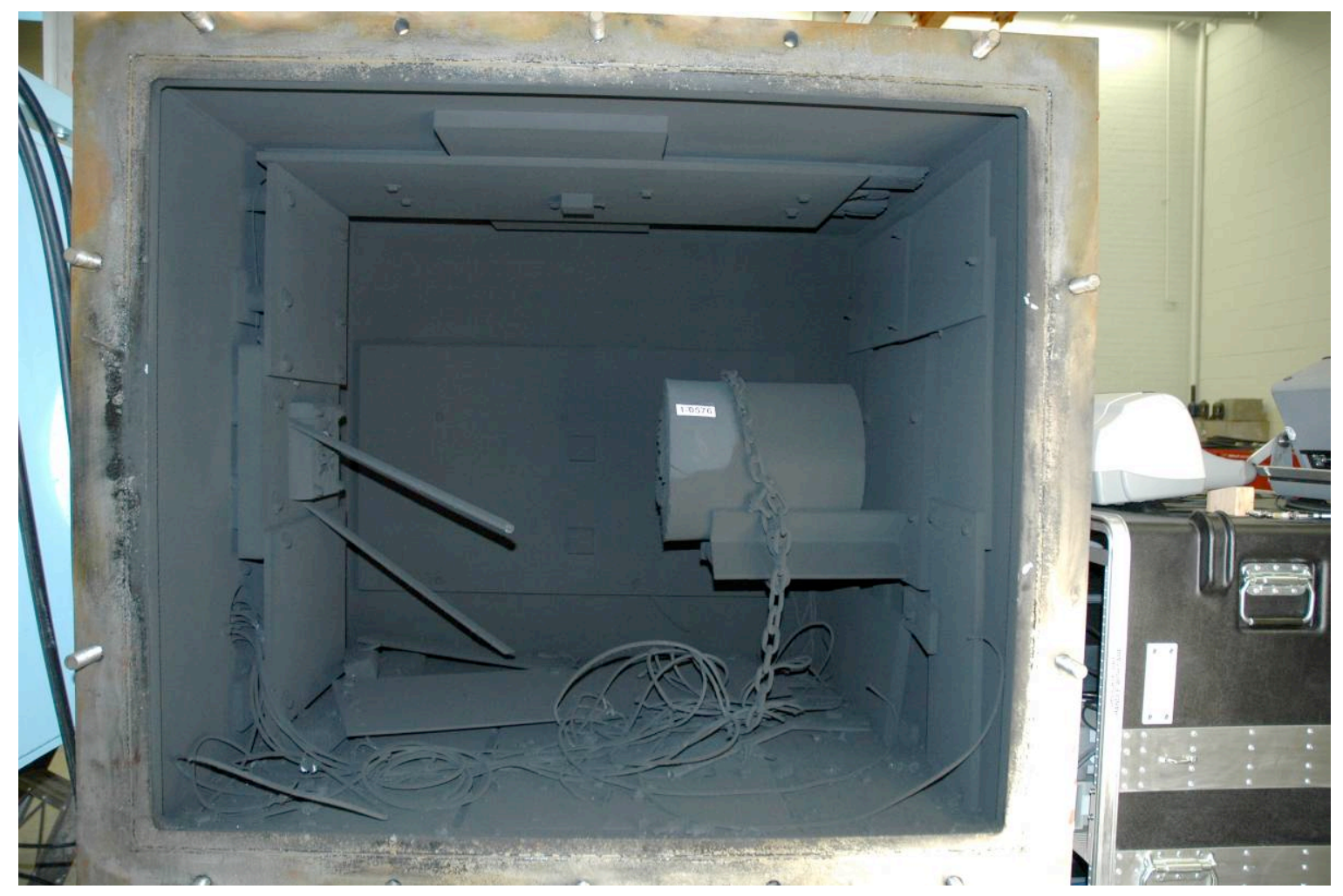

Figure 20. Post Impact View of Target Chamber After Shot 1-0576. 


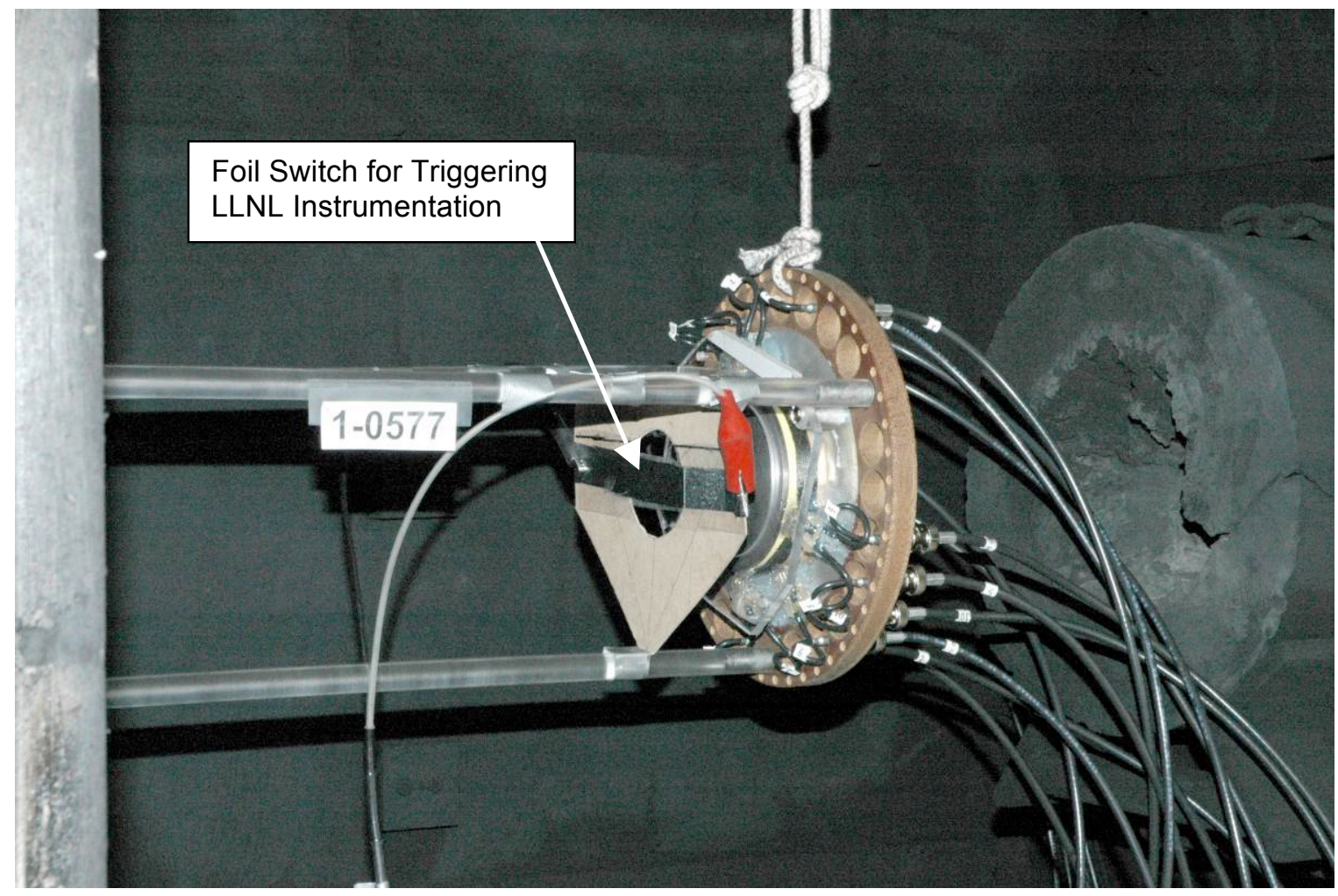

Figure 21. Pre-impact Photo of Target \#9.

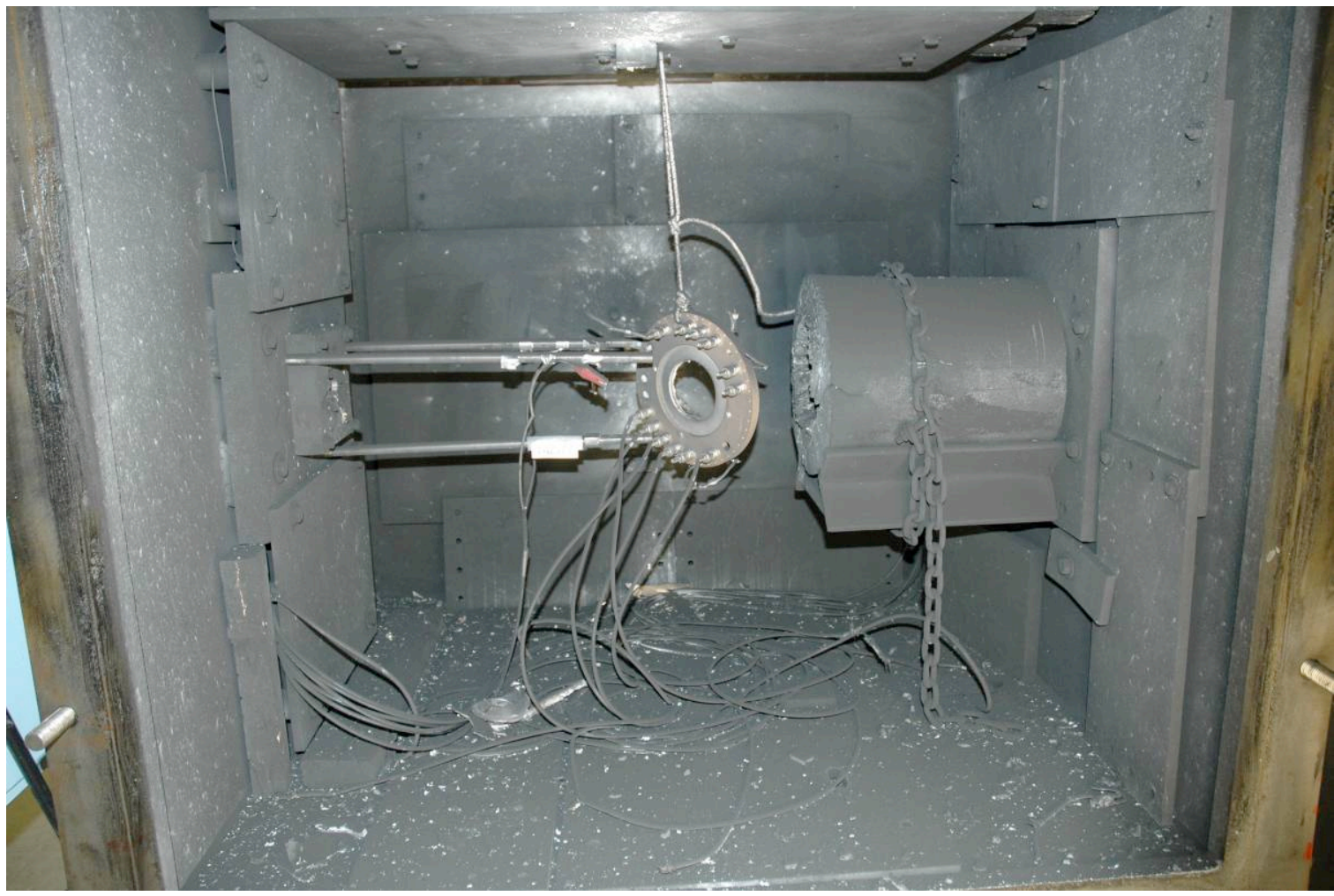

Figure 22. Post Impact View of Target Chamber After Shot 1-0577. 
This report documents impact tests conducted on tantalum faced LX-04 targets during the period of August 18 - 27, 2010 for Lawrence Livermore National Laboratory (LLNL). The primary objective was to validate modeling efforts of the experiments. The impact tests were performed by launching tantalum disks with diameters of $9.4,14.3$, and $24.7 \mathrm{~mm}$ into the targets at impact velocities ranging from $590 \mathrm{~m} / \mathrm{s}$ to $3,112 \mathrm{~m} / \mathrm{s}$.

The $9.4 \mathrm{~mm}$ diameter tantalum disks impacting at 1,788 m/s, 2,617 m/s, and 3,112 m/s resulted in full detonation of the LX-04.

The $14.3 \mathrm{~mm}$ diameter tantalum disks impacting at $1,639 \mathrm{~m} / \mathrm{s}$ and 2,084 m/s resulted in full detonation of the LX-04. One $14.3 \mathrm{~mm}$ diameter disk impacting at $1,877 \mathrm{~m} / \mathrm{s}$ resulted in only a partial detonation due to a high projectile inclination impact as evidenced by the entrance hole in the recovered tantalum target face.

The $24.7 \mathrm{~mm}$ diameter tantalum disks impacting at $922 \mathrm{~m} / \mathrm{s}$ and 1,065 m/s resulted in full detonation of the LX-04. One $24.7 \mathrm{~mm}$ diameter disk impacting at $590 \mathrm{~m} / \mathrm{s}$ resulted in only a partial detonation with substantial chunks of LX-04 recovered from the target chamber.

LLNL captured target pressure measurements with manganin gages. This data is not documented in this report. 


\section{APPENDIX A}

\section{Pre-Impact Projectile Radiographs}

Notes: The "S" in front of the test number refers to the Side view.

The " $T$ " in front of the test number refers to the Top view.

The projectiles were not captured on shots 4-2063, 4-2065, and 4-2067 due to a malfunctioning time delay generator.

A projectile image was captured at two different times for shots 1-0575 to 1-0577 to determine if the projectile was spinning substantially during flight. No rotation was observed. 


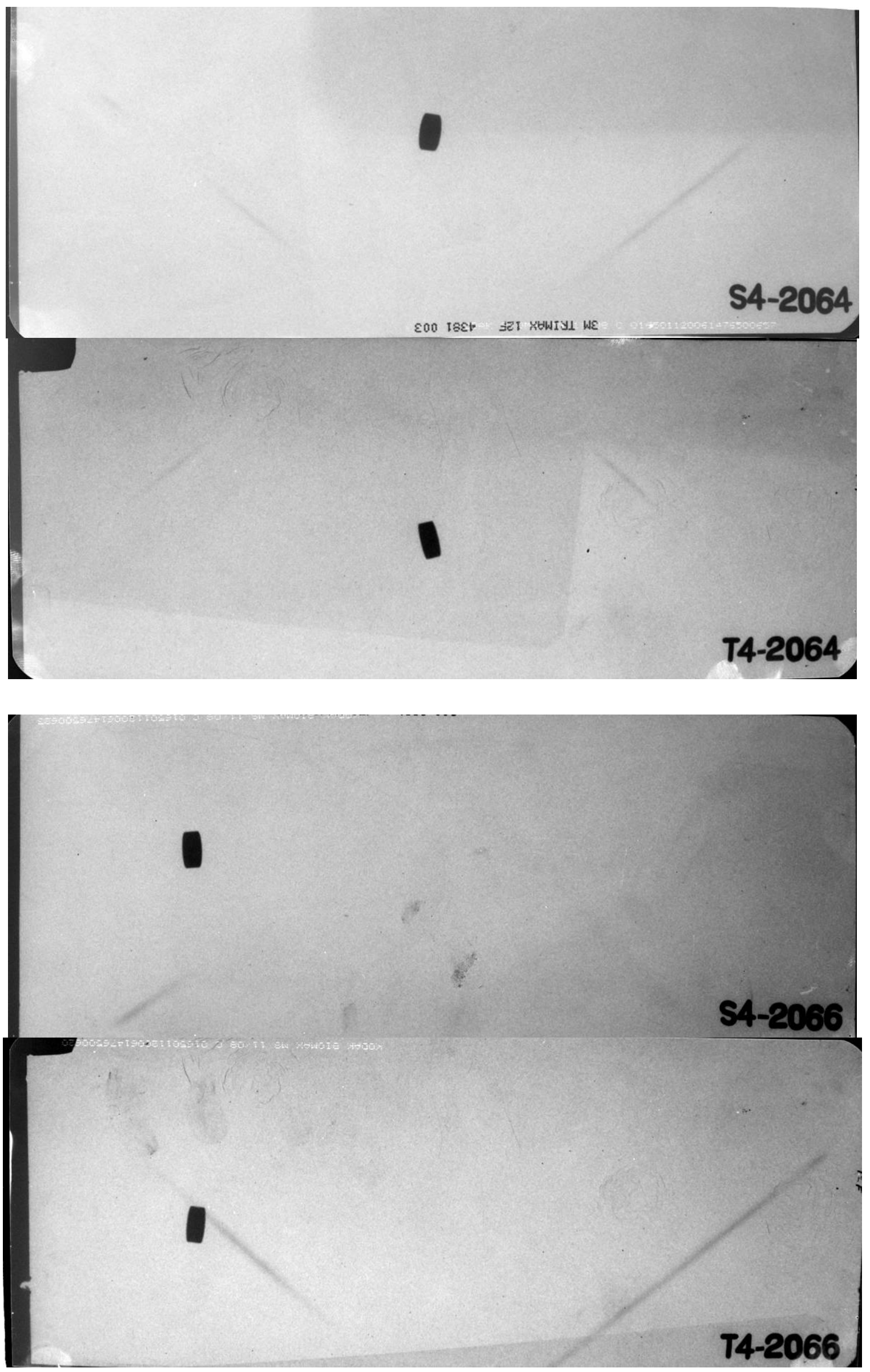




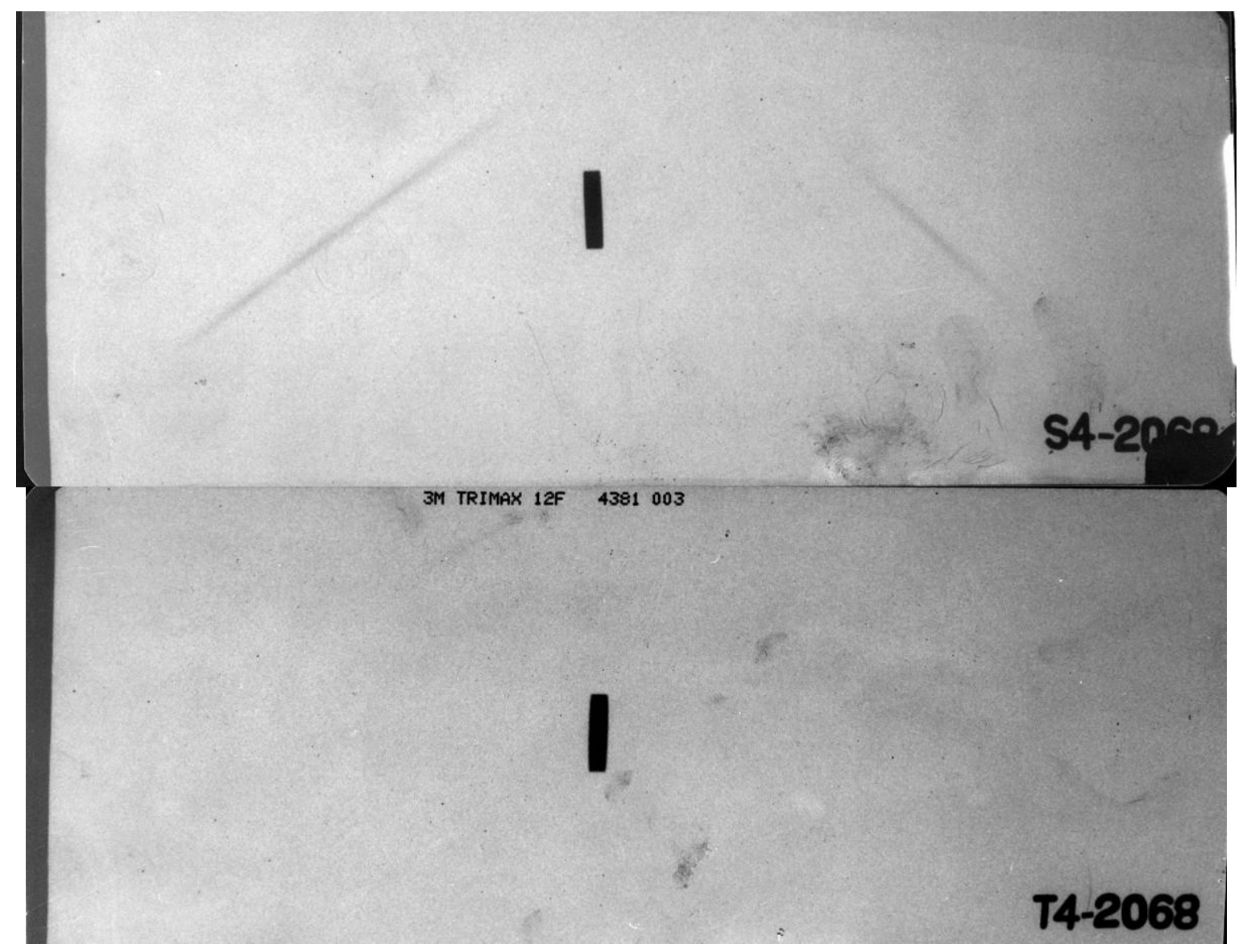

\section{S1-0575}

\section{T1-0575}



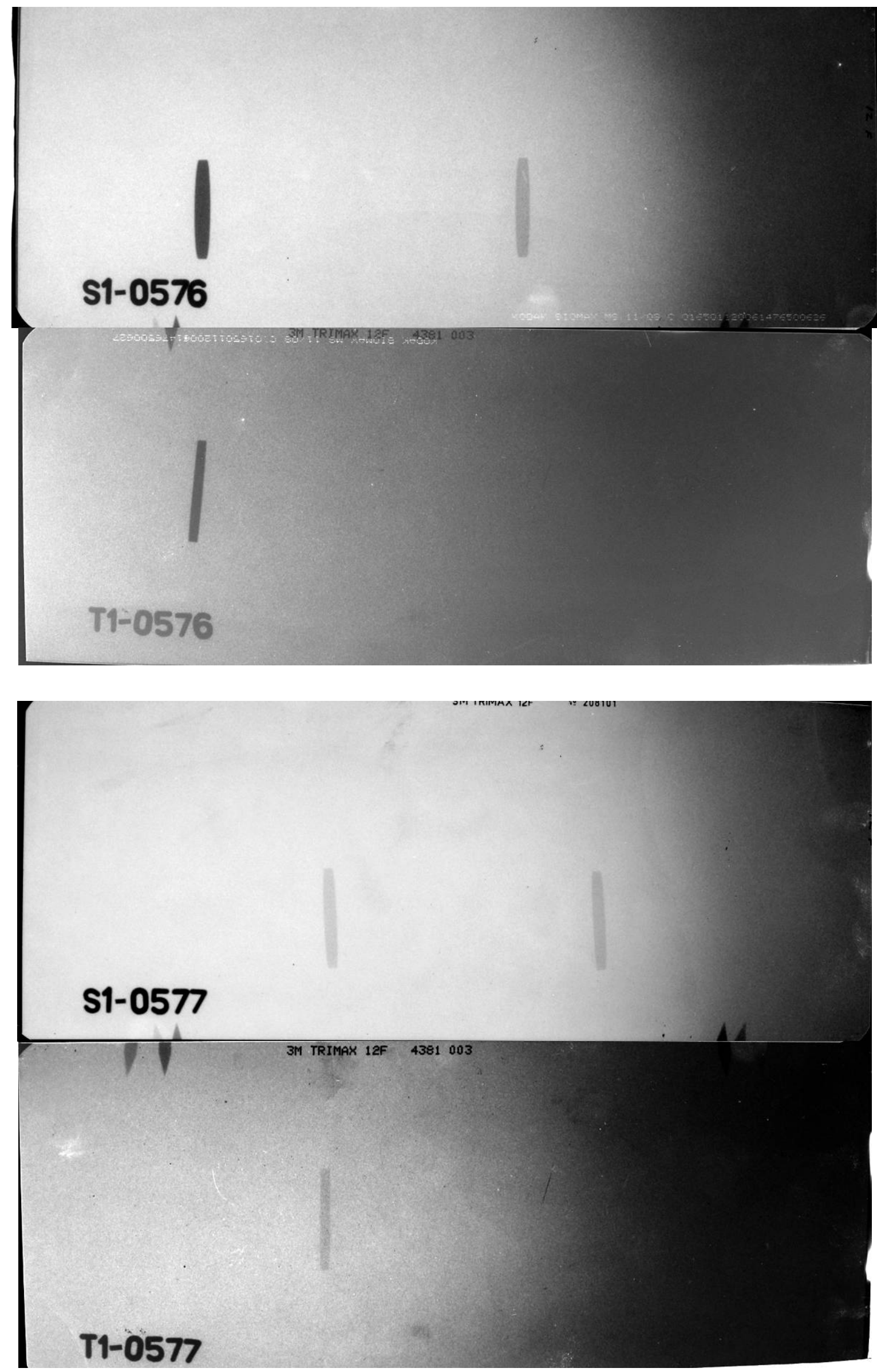


\section{APPENDIX B}

\section{Pressure Transducer Data}



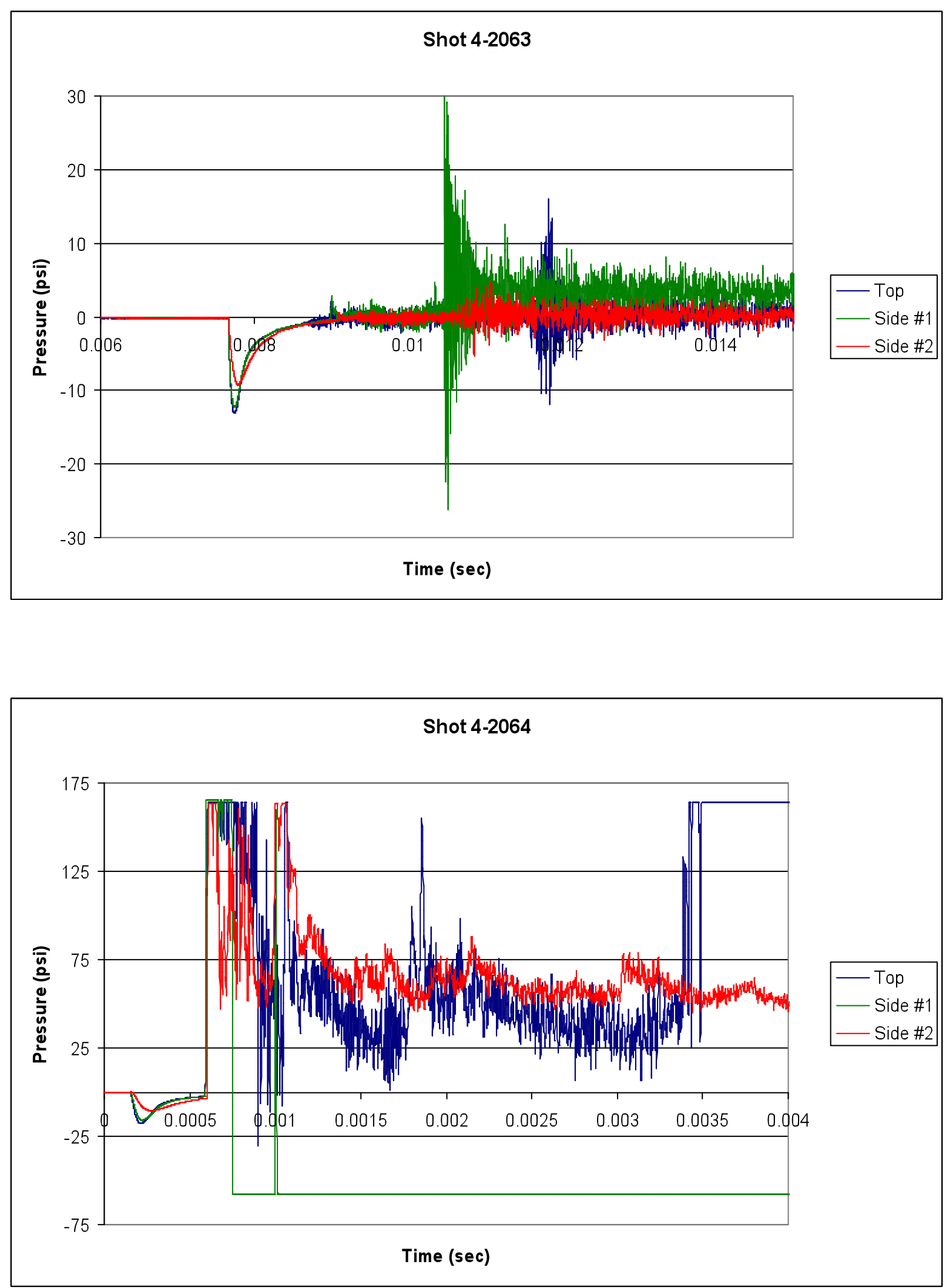

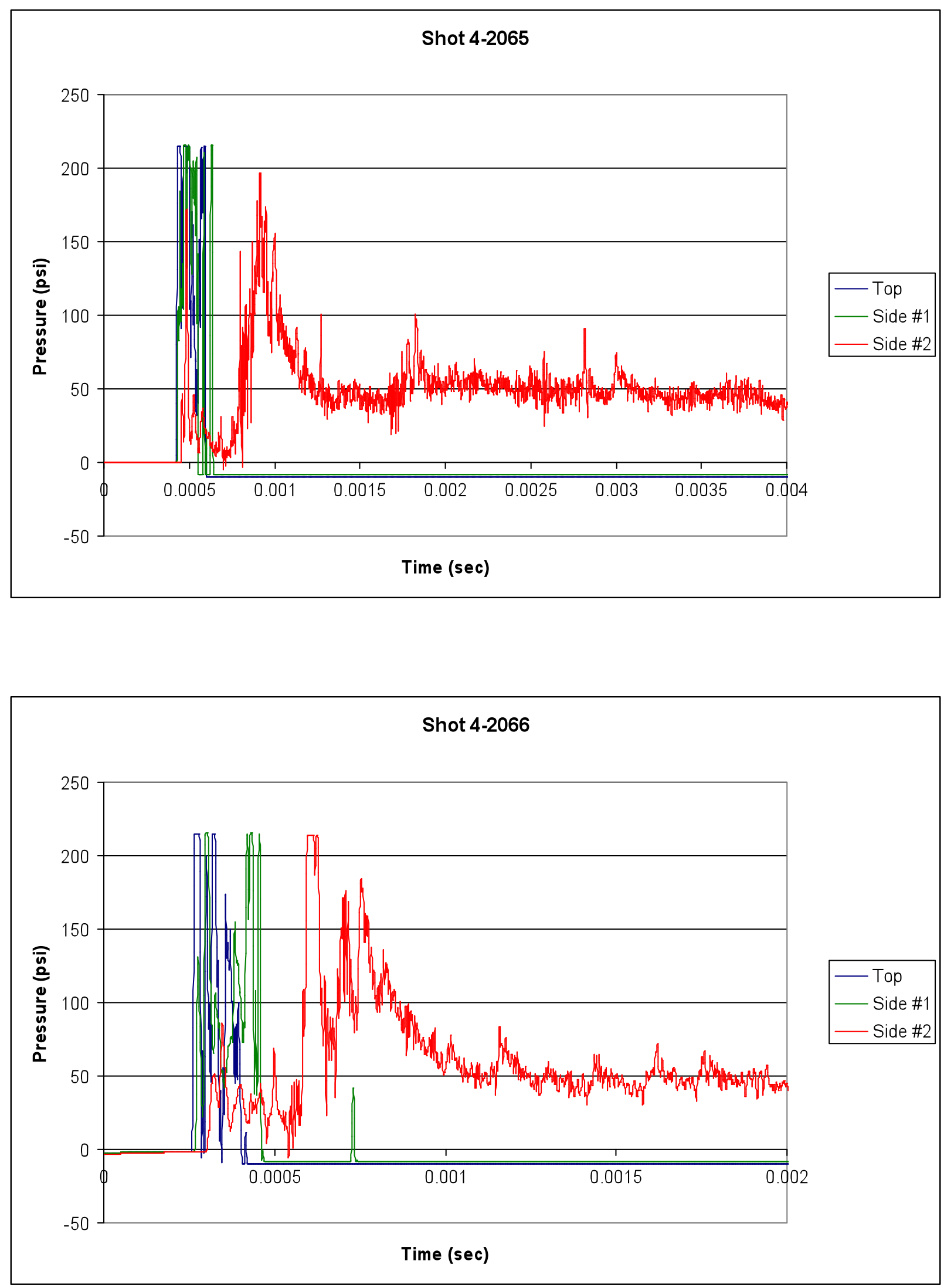

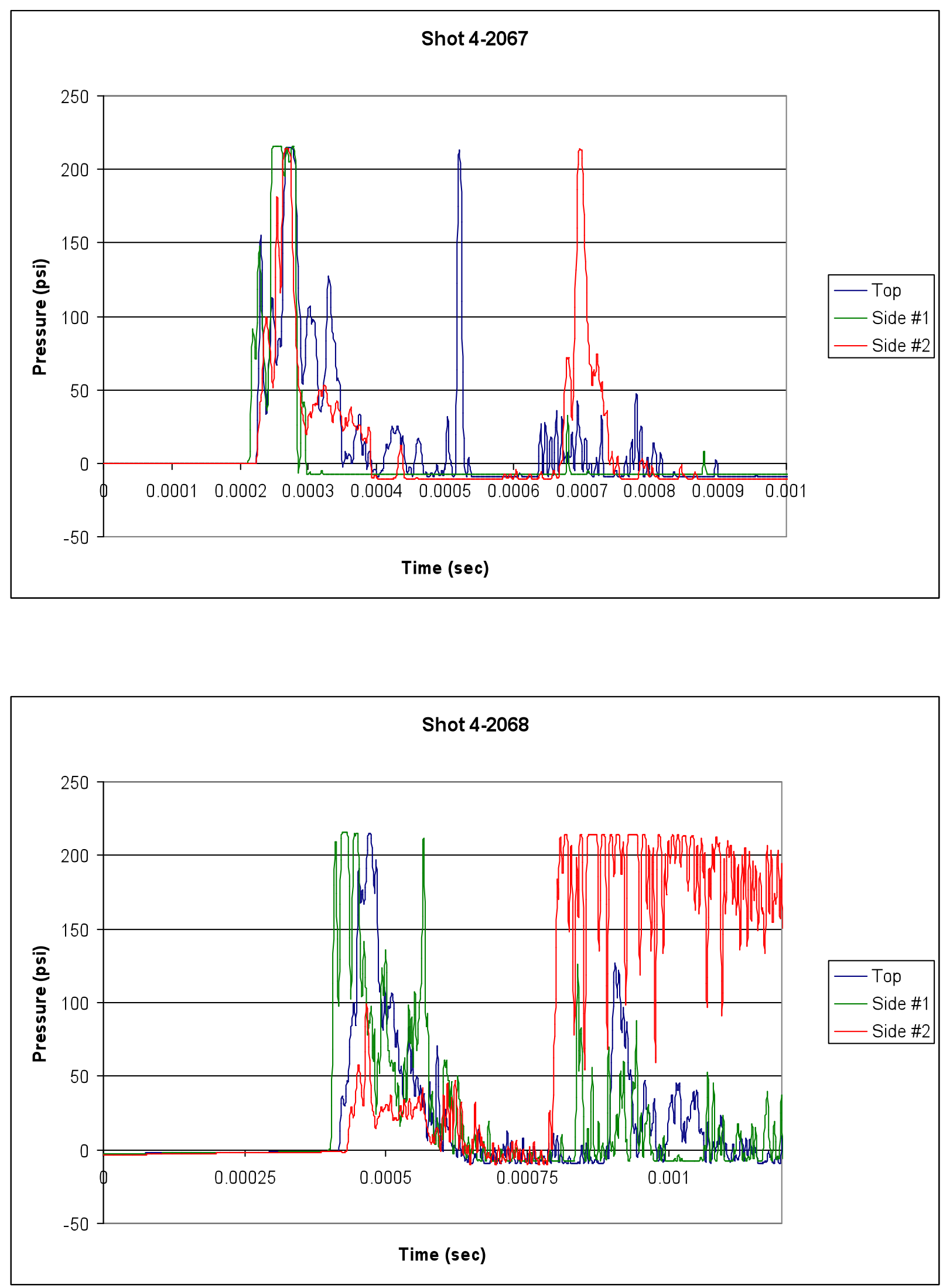

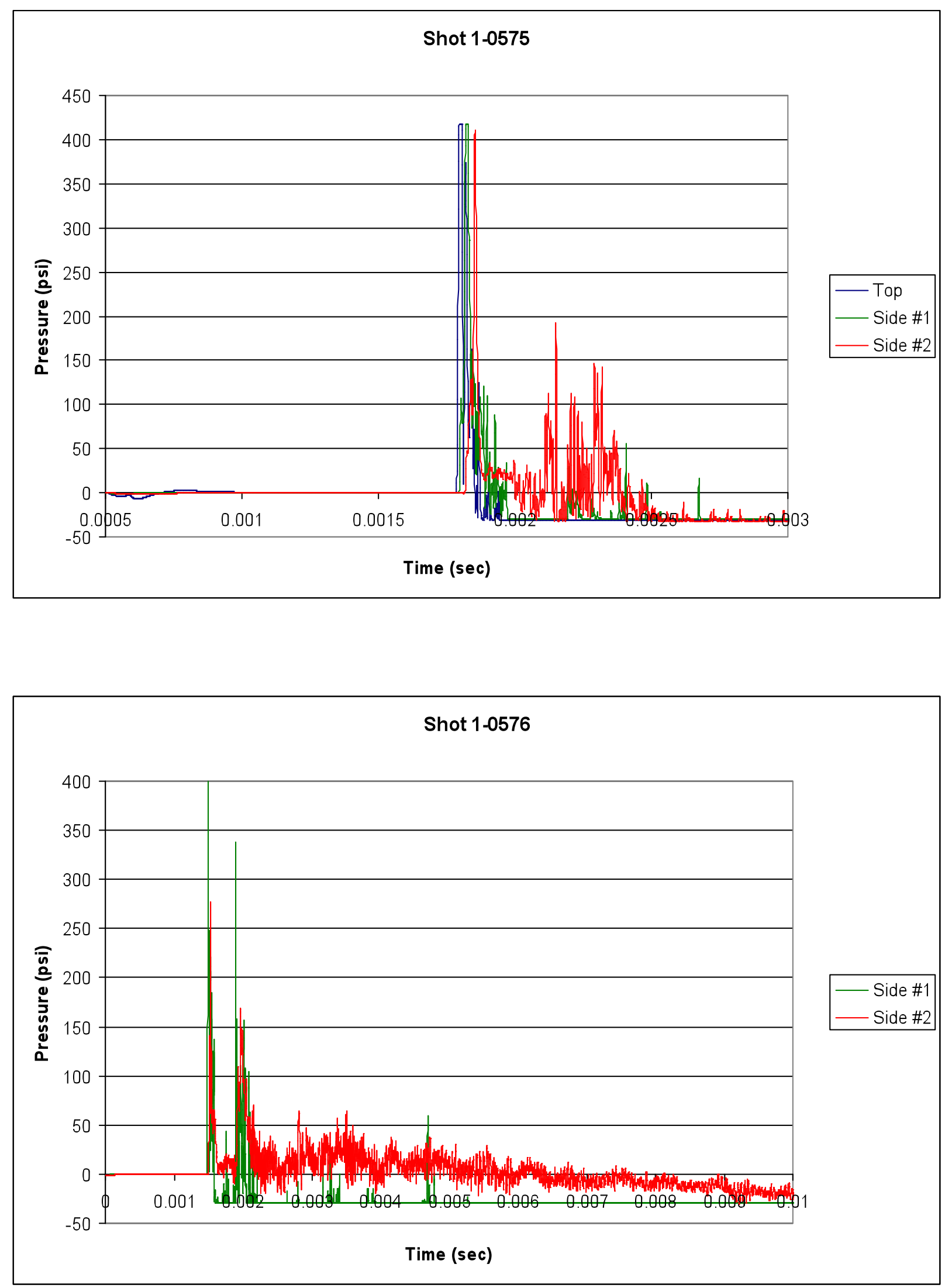


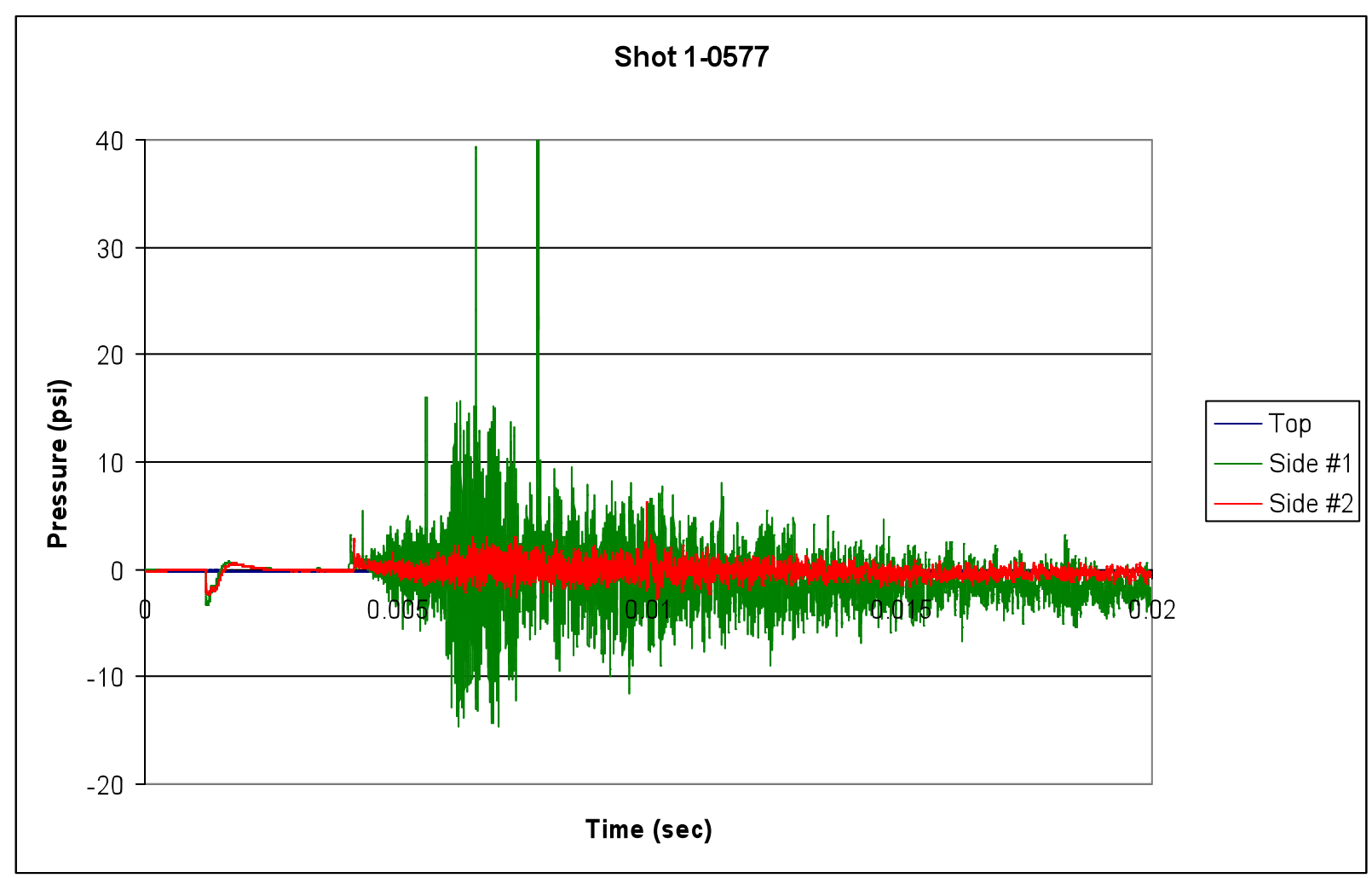

